\title{
Review
}

\section{Nanomedicine in Hepatocellular Carcinoma: A New Frontier in Targeted Cancer Treatment}

\author{
Anita Bakrania ${ }^{1,2,3}$, Gang Zheng ${ }^{3,4,5}$ and Mamatha Bhat $1,2,6,7, *$ \\ 1 Toronto General Hospital Research Institute, Toronto, ON M5G 2C4, Canada; Anita.Bakrania@uhnresearch.ca \\ 2 Ajmera Transplant Program, University Health Network, Toronto, ON M5G 2N2, Canada \\ 3 Princess Margaret Cancer Centre, University Health Network, Toronto, ON M5G 2C1, Canada; \\ gang.zheng@uhnresearch.ca \\ 4 Institute of Biomedical Engineering, University of Toronto, Toronto, ON M5S 3G9, Canada \\ 5 Department of Medical Biophysics, University of Toronto, Toronto, ON M5G 1L7, Canada \\ 6 Division of Gastroenterology, Department of Medicine, University Health Network, \\ Toronto, ON M5G 2C4, Canada \\ 7 Department of Medical Sciences, University of Toronto, Toronto, ON M5S 1A1, Canada \\ * Correspondence: Mamatha.Bhat@uhn.ca; Tel.: +1-416-340-4800 (ext. 6221)
}

check for updates

Citation: Bakrania, A.; Zheng, G.;

Bhat, M. Nanomedicine in

Hepatocellular Carcinoma: A New

Frontier in Targeted Cancer

Treatment. Pharmaceutics 2022, 14, 41.

https://doi.org/10.3390/

pharmaceutics14010041

Academic Editors: Elena Mourelatou,

Sophia Hatziantoniou and

Eleftheria Galatou

Received: 19 November 2021

Accepted: 22 December 2021

Published: 25 December 2021

Publisher's Note: MDPI stays neutral with regard to jurisdictional claims in published maps and institutional affiliations.

Copyright: () 2021 by the authors. Licensee MDPI, Basel, Switzerland. This article is an open access article distributed under the terms and conditions of the Creative Commons Attribution (CC BY) license (https:// creativecommons.org/licenses/by/ $4.0 /)$.

\begin{abstract}
Hepatocellular carcinoma (HCC) is the third leading cause of cancer-related death and is associated with a dismal median survival of 2-9 months. The fundamental limitations and ineffectiveness of current HCC treatments have led to the development of a vast range of nanotechnologies with the goal of improving the safety and efficacy of treatment for HCC. Although remarkable success has been achieved in nanomedicine research, there are unique considerations such as molecular heterogeneity and concomitant liver dysfunction that complicate the translation of nanotheranostics in HCC. This review highlights the progress, challenges, and targeting opportunities in HCC nanomedicine based on the growing literature in recent years.
\end{abstract}

Keywords: hepatocellular carcinoma; liver cancer; nanoparticle; nanomedicine; gene therapy

\section{Introduction}

Hepatocellular carcinoma (HCC) is the predominant form of primary liver cancer and the fifth most common cancer globally [1]. It has a high mortality rate causing over 600,000 deaths annually worldwide. Due to the insidious growth nature of HCC, the majority of patients are diagnosed at advanced stages of the disease, at which point available therapeutic options are limited and ineffective [2].

Cirrhosis arises in the setting of chronic liver diseases such as hepatitis $\mathrm{C}(\mathrm{HCV})$ infection, alcoholic liver disease (ALD), non-alcoholic steatohepatitis (NASH), and hemochromatosis (resulting in liver iron overload). HCC does also arise in the setting of hepatitis $B$ virus (HBV) infection even without cirrhosis, given the ability of HBV to stimulate oncogenesis through integration into the liver cell DNA [3]. Additionally, aflatoxin B1, a secondary metabolite of a few Aspergillus fungi species, is a known potent mycotoxin ingested through staple food contamination and a major cause of HCC in high-risk geographical regions of Africa and Asia [4-6]. Furthermore, anti-diabetic agents such as sulfonylureas and insulin $[7,8]$ are associated with an increased risk of HCC in contrast to metformin [7,9-12] and thiazolidinediones [7,13], which are associated with a reduced risk of HCC development. Other medications such as statins [14,15] and aspirin [16] have been shown to reduce the risk of HCC incidence [17].

The treatment of HCC depends on various factors, including the tumor stage, patient performance status, and liver functional reserve, thereby requiring a multidisciplinary approach. Current treatment options reserved for early-stage HCC include local ablative therapies, resection, and liver transplantation [18]. Systemic therapies and transarterial radioembolization (TACE) are the only available treatment options for advanced-stage 
disease $[19,20]$. Among the targeted therapies, sorafenib was the first systemic drug that showed efficacy in advanced HCC and had remained the standard of care as first-line therapy for over 10 years [21-24]. After a decade of negative trials, the approvals of lenvatinib as first-line along with regorafenib, carbozantinib, and recombinant immunoglobulin G1 (IgG1) monoclonal antibody ramucirumab as second-line post-sorafenib in early 2019 paved the way to sequential systemic therapy in HCC [25-30]. Recently in 2020, the combination of atezolizumab and bevacizumab also received FDA approval and showed significant improvement in the overall and progression-free survival outcomes compared to sorafenib in unresectable or metastatic HCC [31,32]. Atezolizumab selectively targets programmed death ligand 1 (PD-L1), thus reversing T-cell suppression, while bevacizumab is a monoclonal antibody targeting vascular endothelial growth factor (VEGF), thus inhibiting angiogenesis and tumor growth [33-35].

Alongside the glimmers of real hope with the enormous recent progress in HCC therapy and opportunities that lie ahead, the current challenges cannot be overlooked. The current overall outcome still remains unsatisfactory, with median survivals in early and advanced HCC of 6-9 months and 1-2 months, respectively [36]. The mortality is often not due to the tumor itself but the complications associated with cirrhosis, such as ascites, variceal hemorrhage, hepatic encephalopathy, and hepatorenal syndrome. Henceforth, therapeutic strategies should aim at not only eradicating tumors but also, more specifically, targeting the tumor cells and strengthening the host immune system. Additionally, these drugs are associated with significant side effects, particularly in patients with concomitant cirrhosis and liver dysfunction.

Chemotherapeutic agents focus on specific carcinogenic pathways to limit systemic side effects. Unfortunately, there is no single dominant pathway that exists for the development of HCC. Overexpression of multiple signaling pathways has been implicated in the pathogenesis of HCC, including epidermal growth factor (EGF), VEGF, Ras mitogenactivated protein kinase (MAPK), insulin-like growth factor receptor (IGFR), phosphoinositide 3-kinase (PI3K)/phosphatase, and tensin homolog (PTEN)/Akt/mammalian target of rapamycin (mTOR), hepatocyte growth factor/c-MET and Wnt/ $\beta$-Catenin pathways providing a wide scope to hunt newer targets for HCC treatment.

Nanotechnology has emerged as an immensely advancing field and a novel possibility to overcome current challenges in HCC therapy. This is largely attributable to its unique features for drug delivery, specific targeting, enhancement of pharmaceutical properties, co-delivery of multiple drugs, visualization of sites of drug delivery by combination with imaging modalities, and the therapeutic nature of some nanomaterials themselves, for example, gold nanoshells and nanorods [37-44]. However, rapid sequestration of particulate carriers by Kupffer cells severely limits the tumoral hepatocyte accumulation, seriously compromising therapeutic efficacy. Therefore, targeted delivery to tumoral hepatocytes via receptors that are overexpressed on these cells represents a promising strategy for HCC targeting [45]. This review aims to identify gaps in our understanding of HCC targeting and why nanomedicine has yet to fulfill its promise in HCC treatment and to offer an overview of the emerging targeting opportunities in the field of nanotherapeutics for HCC treatment.

\section{Progress in HCC Nanomedicine}

Nanotechnology has been progressively advancing ever since it was first introduced in 1974, with exceptional development in cancer research [46,47]. With the augmenting interest in HCC nanomedicine, several studies have been conducted and are currently ongoing to overcome the challenges in specific targeted drug delivery to HCC. Although most nanoparticles tend to accumulate in the liver, thereby defining it as an easy target, the occurrence of HCC in the setting of cirrhosis makes it a greater challenge than expected. Since most drugs must pass through the liver as the primary metabolism site, the altered pharmacokinetics in a cirrhotic liver represents a challenge. Along with that, selectively targeting tumoral hepatocytes defines another obstacle. Therefore, a selectively targeted 
therapy is desirable in order to selectively target the affected cells while reducing the toxicity of the therapy [48]. Evolving research has developed a broad range of nanoparticles for HCC, which include alumina NPs [49], arsenite NPs [50-52], albumin NPs [53], calcium NPs [54-57], chitosan NPs [58-62], gold NPs [63-73], halifum oxide NPs [74], iron oxide NPs [75-80], lipid NPs [81-84], poly(ethylene glycol) (PEG) NPs [85-94], platinum NPs [95,96], poly(lactic-co-glycolic acid) (PLGA) NPs [87-94,97-102], polysaccharide NPs [45,103,104], selenium NPs [105-107], silica NPs [108-118], silver NPs [119-122], zinc oxide NPs [123], etc. [47].

Subsequently, there has also been progress in the drug/cargo of interest to be delivered through the above-mentioned nano vehicles, with the most recent strategy being gene engineering [124-127]. Since the primary cause of HCC tumors lies in the dysregulation of various proto-oncogenes and tumor-suppressive genes of several signaling pathways, genome engineering offers a unique approach to HCC treatment via nanotechnology by introducing nucleic acids that edit and code for the abnormal gene and/or suicide gene through interfering RNAs such as miRNA, siRNA, piRNA, and shRNA [128-140].

\section{Current Challenges in Treating HCC}

\subsection{Tumor Microenvironment}

Recent research has highlighted the link between tumor cells and their surrounding microenvironment along with the fundamental role of the tumor microenvironment in hepatocarcinogenesis [141]. The tumor microenvironment is composed of; (1) cells such as hepatic stellate cells, fibroblasts, immune cells, including regulatory and cytotoxic $\mathrm{T}$ cells and tumor-associated macrophages (TAMs), and endothelial cells, (2) proteolytic enzymes including matrix metalloproteinases (MMPs) and tissue inhibitor of metalloproteinases (TIMPs), (3) growth factors, for example, transforming growth factor b1 (TGF- $\beta 1$ ) and platelet-derived growth factor (PDGF), 4) inflammatory cytokines, and (5) extracellular matrix (ECM) [142-145]. An interesting phenomenon called enhanced permeability and retention (EPR), responsible for the formation of leaky vessels and pores of diameter $100 \mathrm{~nm}$ to $2 \mu \mathrm{m}$, thereby providing an advantage to the design of novel antitumor nanoparticles for tumor targeting in all types of tumors [146-149]. The EPR effect increases nanoparticle accumulation at the tumor site resulting in a more specific therapeutic targeting along with reduced toxicity of the therapeutic agents due to membrane hyperpermeability and absence of basement membrane in the tumor vasculature compared to normal tissue blood vessels [150-152]. Although the liver vasculature inherently possesses leaky vessels, the vasculature abnormalities in the presence of chronic liver diseases such as cirrhosis are ubiquitous [153]. Therefore, designing and developing different nano systems with particle size within the vasculature to selectively target HCC tumor cells would enable an effective drug delivery system in the setting of liver diseases. Another characteristic of the HCC tumor environment is the low extracellular $\mathrm{pH}$, which lies between 6.0 and 7.0 as compared to normal tissues and blood with $\mathrm{pH}$ 7.4. This is due to the increased rate of glycolysis leading to accumulation of lactic acid in hypoxic tumor cells [154-157]. Changes in $\mathrm{pH}$ play a role in the delivery of therapeutic agents to the liver tumor cells: an acidic $\mathrm{pH}$ favors the cellular uptake of weakly acidic drugs and delays the uptake of weakly basic drugs. This consideration can also inform the synthesis of nanoparticles to provide optimal HCC tumor targeting.

\subsection{Physiological Barriers to Nanomedicine Targeting HCC Cells}

\subsubsection{Coronal Protein Adsorption}

Protein corona refers to the bound or adsorbed proteins around nanoparticles while they are exposed to various physiological fluids in the systemic circulation. Some of the most abundant proteins include transferrin, fibrinogen, albumin, complement C3, haptoglobin, $\alpha$-2-macroglobulin, and immunoglobulins A, M, and G [158]. This exposure is inevitably responsible for altering their overall pharmacological and toxicological profile and ultimately triggers an unpredictable therapeutic function. Some of the physicochemical 
factors responsible for coronal protein adsorption include nanoparticle material hydrophilicity/hydrophobicity, surface charge, size, and shape [158-162]. Studies have shown that a decrease in nanoparticle size decreases the surface interaction impacting the protein conformation, and similarly, a spherical shape of nanoparticles offers increased mass/surface ratio that overall reduces interaction with the proteins in the environment [163-165]. Additionally, the nature of the nanoparticle also plays a crucial role in the formation of the protein corona such that hydrophilic nanoparticles attract charged proteins via electrostatic forces, while hydrophobic nanoparticles bind to hydrophobic proteins through van der Waal's or $\pi-\pi$ interactions [162,166]. Lastly, the surface charge promotes protein corona formation in instances where the nanoparticles are highly charged as compared to slightly negatively charged nanoparticles, which offer the least protein interactions and therefore avoid the corona formation $[167,168]$.

Over the past few years, there has been progressive understanding regarding the effect of protein coronas on nanoparticles. Taking a glance at its formation, initially, when the nanoparticles encounter biological fluids, a "soft" corona is formed that represents a loosely bound and rapidly exchanging layer of the highly abundant proteins adsorbed during circulation. Following this, it is further coated with other proteins of high affinity as per the Vroman effect and is now termed as "hard" corona [169-171]. This leads to a decrease in enthalpy and displacement of the hydration layer surrounding the nanoparticles, subsequently enhancing entropy. Eventually, this causes (i) increased nanoparticle solubility in an aqueous environment, (ii) enhanced protein aggregation and misfolding, (iii) protein conformational changes leading to phagocytosis, and (iv) mask the nanoparticle components defining its pharmacological function [161]. Additionally, the HCC environment plays a major role in coronal protein adsorption, including its composition, exposure time, $\mathrm{pH}$, temperature, and shear stress [172-174]. These factors have the capacity to influence the composition of the protein corona as well. Several strategies have been employed to date to overcome this phenomenon; for example, nanoparticle preparation with carbohydrate moieties, dysopsonic proteins, zwitterions, and hydrophilic "stealth" polymers such as PEG could help escape opsonization, ensuring efficient delivery of the nanoparticles [175-179]. In HCC, it is important to enhance the targeting capability of nanoparticles without the hindrance of the protein corona for the most efficient and optimal targeted therapy considering the above-mentioned challenges that pre-exist in HCC targeting. This can be achieved by personalizing the protein corona using specific noncovalent antibodies for HCC or new targeting ligands considering disease heterogeneity [180-182].

\subsubsection{Mononuclear Phagocyte System}

The mononuclear phagocyte system (MPS), previously known as the reticulo-endothelial system (RES) of the human liver, is composed of three major types of cells, namely, monocytes, macrophages (Kupffer cells), and dendritic cells that play a vital role in immune response balance through their function in antigen presentation and therefore, rapidly sequester nanoparticles upon entry to the liver [183-188]. Although in-depth research is of the utmost importance to accurately define the subsets of the MPS cells within the liver tissue, it has been reported that the resident phagocytosing Kupffer cells of the liver potentially uptake and get rid of systematically circulating nanoparticles based on various factors, including size and charge $[189,190]$. This leads to significant restriction to HCC targeting, and therefore, it is vital for nanoparticles to escape this non-specific uptake by Kupffer cells before they reach the HCC cells. The effect of removing these live phagocytosing cells during nano delivery has been investigated. The results showed that although there was an improvement in tumor targeting, nanoparticle delivery efficiency was not drastically changed, and these cells contributed merely $2 \%$, which concludes that designing nanoformulations should be a balancing act between tumor cell specificity, organ targeting, and escape from phagocytosis [191-193]. The most common technique used to overcome phagocytosis by the liver involves the modification of nanoparticle surfaces with charge-neutral, highly hydrophilic, "stealth" polymers such as PEG and 
poly(vinyl alcohol) (PVA) [194,195]. Another approach is to apply zwitterionic coatings on nanoparticles that are overall neutral in charge but dually contain positively and negatively charged groups such as poly(carboxybetaine), poly(sulfobetaine), 2-methacryloyloxyethyl phosphorylcholine, and poly(maleic anhydride-alt-1-alkene) derivatives as a crucial step for more directed delivery of the nanoparticulate system into HCC cells [196].

\section{Targeting Opportunities for HCC Nanomedicine}

\subsection{Surface Biomarkers for Specific Targeting to HCC}

\subsubsection{Asialoglycoprotein Receptor (ASGPR)}

ASGPR was first identified by Morell and Ashwell in 1974 as a 40-50 kDa noncovalent hetero-oligomer composed of two homologous poly-peptides with the major and minor subunits HL-1 (hepatic lectin, or ASGPR1, ASGR1) and HL-2 (ASGPR2 or ASGR2), respectively [197-200]. It is a trans-membrane molecule found in abundance on hepatocytes (500,000 ASGPR/hepatocyte) and specifically expressed on the sinusoidal and basolateral hepatocellular membranes excluding the bile canalicular membrane [201]. The hepatic ASGPR plays an essential role in the clearance of desialylated proteins from the serum via endocytosis and lysosomal degradation. In addition, hepatic ASGPR is involved in the binding, internalization, and degradation of extracellular glycoproteins with exposed terminal galactose, lactose, or $\mathrm{N}$-acetyl-galactosamine residues making it an ideal receptor for galactose-mediated delivery of anti-cancer drugs to the liver (Figure 1) [202-204]. The natural ligands of ASGPR include asialoorosomucoid (ASOR, high-affinity ligand with $K i=1.7 \mathrm{nM} ; 20 \mathrm{Gal})$, asialoceruloplasmin (86 nM; $12 \mathrm{Gal})$, asialofectin (17 nM; $12 \mathrm{Gal}$, 3 GalNAc), and asialotransferrin (3300 nM; 5 Gal) where Gal and GalNAc define the number of galactoses and galactosamines, respectively [205]. Several studies have been conducted to understand the role of targeting ASGPR for HCC after the proof-of-concept that demonstrated that GalNAc-conjugated siRNA specifically accumulated in the hepatocytes [206,207]. Interestingly, ASPGR targeting has also been studied in two clinical studies as a strategy to exploit this receptor as targeted therapy, thereby lowering the risk of adverse effects in extra-hepatic non-ASGPR expressing tissues [208,209]. However, a crucial consideration for galactose-mediated delivery is that ASGPR1 expression exhibits polarity and zonality on the surface of hepatocytes such that it is highly expressed on the basolateral/sinusoidal membrane of hepatocytes and low on the apical hepatocellular membrane (polarity). Similarly, its expression is higher in the hepatocytes in the centrolobular areas as compared to the portalobular regions (zonality) [210]. Several studies have demonstrated the use of nanotechnology in ASGPR targeting in HCC (Table 1).

Table 1. Different nanoformulations showing ASGPR targeting in HCC.

\begin{tabular}{|c|c|c|c|}
\hline Targeting Moiety & Nanocarrier & $\begin{array}{c}\text { Cargo Carried by } \\
\text { Nanocarrier }\end{array}$ & In Vitro and/or In Vivo Studies and Results \\
\hline $\begin{array}{l}\text { Pullulan (Pul), } \\
\text { Arabinogalactan (AGn), } \\
\text { and Pul-AGn [45] }\end{array}$ & $\begin{array}{l}\text { Polyethylene sebacate } \\
\text { (PES) nanoparticles }\end{array}$ & Doxorubicin & $\begin{array}{l}\text { ASGPR-mediated uptake in HepG2 cells, } \\
\text { biodistribution and hepatic disposition in vivo } \\
\text { and antitumor activity and toxicity testing } \\
\text { in vivo showed that Pul and Pul-AGn labeling } \\
\text { increased liver uptake with hepatocyte: } \\
\text { nonparenchymal cell ratio of } 85: 15\end{array}$ \\
\hline Lactose [211] & $\begin{array}{l}\text { Shell cross-linking } \\
\text { nanoparticles }\end{array}$ & Doxorubicin & $\begin{array}{l}\text { In vitro cytotoxicity and cellular uptake in } \\
\text { HepG2 cells showed that lactose conjugated } \\
\text { NPs were internalized through a } \\
\text { lactose-mediated mechanism }\end{array}$ \\
\hline Galactose [212] & Cyclodextrins & Not applicable & $\begin{array}{l}\text { In vitro and in vivo adherence of hepatocytes to } \\
\text { formulation proved that the enzymatically } \\
\text { synthesized NPs were specific to hepatocytes }\end{array}$ \\
\hline
\end{tabular}


Table 1. Cont.

\begin{tabular}{|c|c|c|c|}
\hline Targeting Moiety & Nanocarrier & $\begin{array}{l}\text { Cargo Carried by } \\
\text { Nanocarrier }\end{array}$ & In Vitro and/or In Vivo Studies and Results \\
\hline Galactose [213] & $\begin{array}{c}\text { Cross-linked } \\
\mathrm{pH} \text {-sensitive micelles }\end{array}$ & Paclitaxel & $\begin{array}{c}\text { In vitro hepatoma targeting in HepG2 cells and } \\
\text { in vivo biodistribution and antitumor studies } \\
\text { showed that galactose conjugated NPs } \\
\text { underwent receptor-mediated endocytosis } \\
\text { mechanism in vitro with enhanced drug } \\
\text { accumulation at the tumor sites in vivo }\end{array}$ \\
\hline Galactosamine [214] & Albumin nanoparticles & Doxorubicin & $\begin{array}{l}\text { In vitro cytotoxicity and cellular uptake in } \\
\text { HepG2 concluded that the NPs were selectively } \\
\text { taken up by HepG } 2 \text { cells due to the surface } \\
\text { ASGPR as opposed to ASGPR-negative cells }\end{array}$ \\
\hline Lactoferrin [215] & PEGylated liposomes & Not applicable & $\begin{array}{c}\text { In vitro cellular uptake in HepG2 lines and } \\
\text { in vivo imaging for targeting in HepG2 bearing } \\
\text { mice showed that cell uptake was efficiently } \\
\text { associated with ASGPR-positive HepG2 cells } \\
\text { compared to negative control along with } \\
\text { increased drug accumulation in tumors treated } \\
\text { with conjugated NPs }\end{array}$ \\
\hline
\end{tabular}
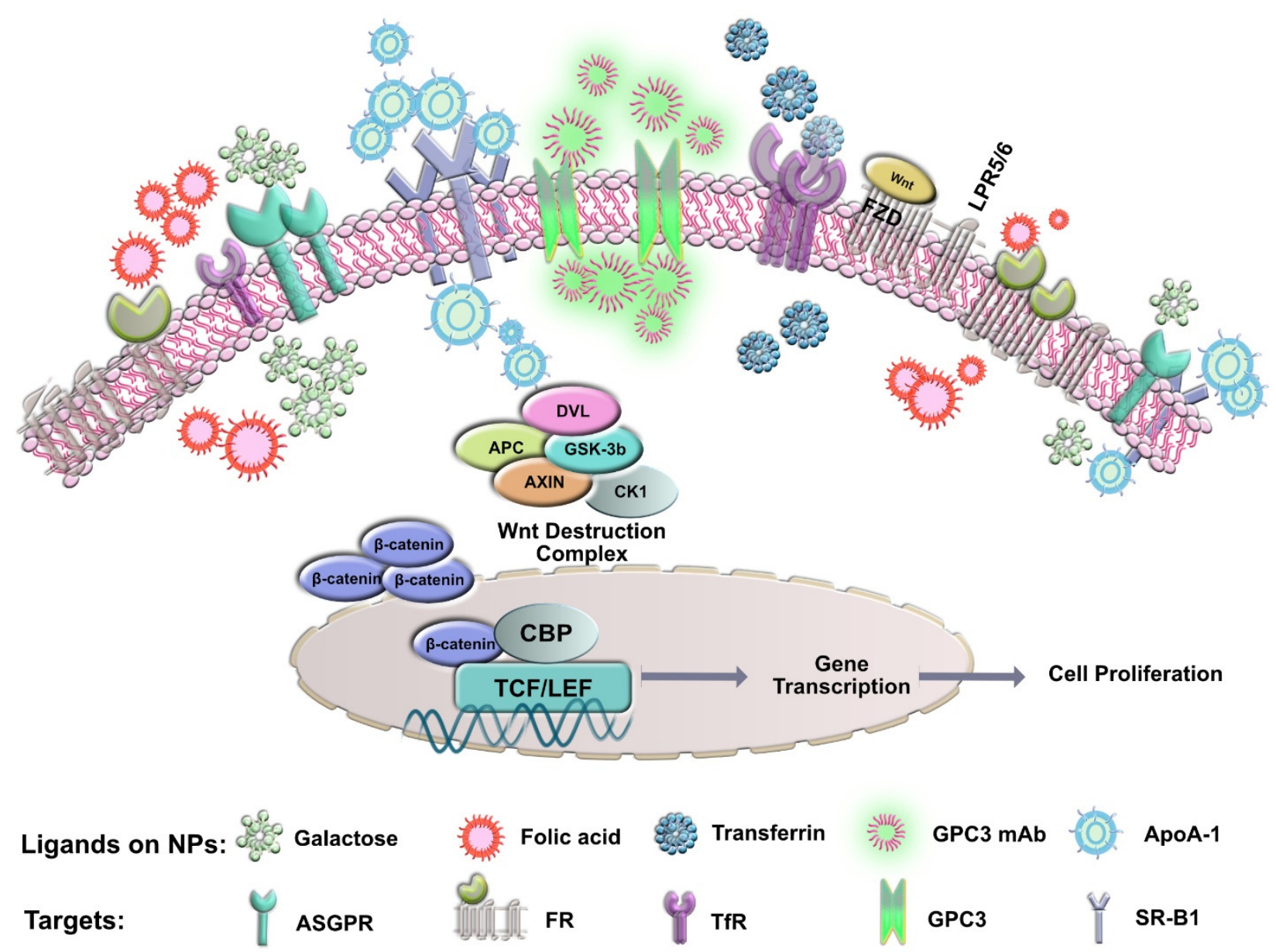

Figure 1. Illustration showing specific targets and ligands for HCC nanomedicine.

\subsubsection{Glypican-3 (GPC3)}

Glypican-3 (GPC3, also known as GTR-2, DGSX, MXR7, OCI-5, SDYS, SGB, SGBS, SGBS1, or heparan sulfate proteoglycan (HSPG)) is a proteoglycan member of the glypican family that is attached to the cell surface by a glycosyl-phosphatidyl-inositol anchor [216-219]. 
The GPC 3 core protein is a $70 \mathrm{kDa}$ protein with a furin cleavage site located in the middle. This furin cleavage leads to the formation of the $40 \mathrm{kDa}$-terminal fragment and the $30 \mathrm{kDa}$ C-terminal fragment [219]. They regulate the signaling activity of several growth factors, including Wnt (Figure 1). Active targeting can overcome barriers to drug delivery by using a moiety that interacts specifically with receptors overexpressed by tumor cells. Studies have shown successful GPC3 targeting for drug delivery to HCC due to its overexpression in the tumor, as opposed to normal and cirrhotic liver, where it is not detected. Previous studies have shown significant success in targeting HCC cells using a humanized anti-GPC3 monoclonal antibody (GC33), and results indicated significant inhibition of GPC3-positive human HCC xenograft tumor growth in SCID mice while the GPC3-negative HCC xenografts were unaffected, proving the potential role of targeting HCC tumor cells through this ligand $[216,220]$. Table 2; Table 3 demonstrate the different antibodies under research and studies that use nanotechnology in GPC3 targeting in HCC.

Table 2. Summary of the various GPC3-targeting antibodies currently under research.

\begin{tabular}{ccccc}
\hline Antibody & Species & Antibody Form & Mechanism of Action & Development Status \\
\hline GC33 [217,220-224] & Humanized mouse & IgG & $\begin{array}{c}\text { Antibody-dependent } \\
\text { cellular cytotoxicity } \\
\text { (ADCC) }\end{array}$ & Phase II \\
YP7 $[217,225]$ & Humanized mouse & IgG & ADCC & Preclinical \\
HN3 $[217,226]$ & Human & VH-hFc & $\begin{array}{c}\text { Inhibition of YAP signaling, } \\
\text { direct inhibition of HCC } \\
\text { cell proliferation }\end{array}$ & Preclinical \\
MDX-1414 [217] & Human & IgG & Not available & Preclinical \\
\hline
\end{tabular}

Table 3. Summary of different nanoformulations designed using GPC3 as a targeting ligand.

\begin{tabular}{|c|c|c|c|}
\hline Targeting Moiety & Nanocarrier & $\begin{array}{c}\text { Cargo Carried by } \\
\text { Nanocarrier }\end{array}$ & In Vitro and/or In Vivo Studies and Results \\
\hline $\begin{array}{l}\text { Peptides specific for } \\
\text { GPC3 [97] }\end{array}$ & Lipid nanoparticles & Sorafenib & $\begin{array}{l}\text { In vitro cytotoxicity, cellular uptake in Hep3B } \\
\text { and SK-Hep1 cells, and in vivo targeting and } \\
\text { antitumor studies in Hep3B xenografts showed } \\
\text { that the effective aqueous solubility of sorafenib } \\
\text { was improved with increased uptake in vivo } \\
\text { In vitro cell uptake and MRI in HepG2 and HLF }\end{array}$ \\
\hline GPC3 mAb [227] & $\begin{array}{c}\text { Iron oxide } \\
\text { nanoparticles }\end{array}$ & $\mathrm{N} / \mathrm{A}$ & $\begin{array}{l}\text { lines confirmed that only GPC3-expressing cells } \\
\text { were specifically targeted using these NPs and } \\
\text { may increase pre-treatment MR imaging } \\
\text { capability for HCC visualization }\end{array}$ \\
\hline GPC3 mAb [228] & $\begin{array}{l}\text { Citrate-coated } \\
\text { nanoparticles }\end{array}$ & Prussian blue & $\begin{array}{l}\text { In vitro cellular uptake and targeted MR } \\
\text { imaging in HepG2 cells confirmed } \mathrm{mAb} \\
\text { targeting cells via receptor-mediated endocytosis } \\
\text { with excellent MR imaging contrast } \\
\text { enhancement ability and biocompatibility }\end{array}$ \\
\hline
\end{tabular}

\subsubsection{Transferrin Receptor (TfR)}

TfR is a glycoprotein that plays an important role in iron regulation and cell growth Iron-bound transferrin has a high affinity for TfR; therefore, the combination of the ligand with the receptor leads to endocytosis through which the iron-bound TfR complex is internalized, releasing the iron and further recycling the receptors back to the surface in an acidic environment [229].

The liver, being the most important organ related to iron storage, is closely linked to iron metabolism and expression of TFR1. Previous literature has shown that iron metabolism is altered in HCC. Significantly higher mRNA levels of genes such as TFR1 participating in the uptake of iron have been detected, making this receptor a potential 
target for active targeting strategies [230-232]. Currently, Tf has been extensively used as a targeting ligand; however, its application is limited due to the presence of high levels of endogenous Tf $(25 \mu \mathrm{M})$ in human blood (Table 4, Figure 1). The endogenous Tf competitively inhibits the Tf-modified drug delivery systems, which may reduce targeting efficiency in vivo and thereby restrict the application of $\mathrm{Tf}$ as a targeting ligand for nanomedicine [233-241].

Table 4. Different nanoformulations using transferrin receptors as a potential HCC target.

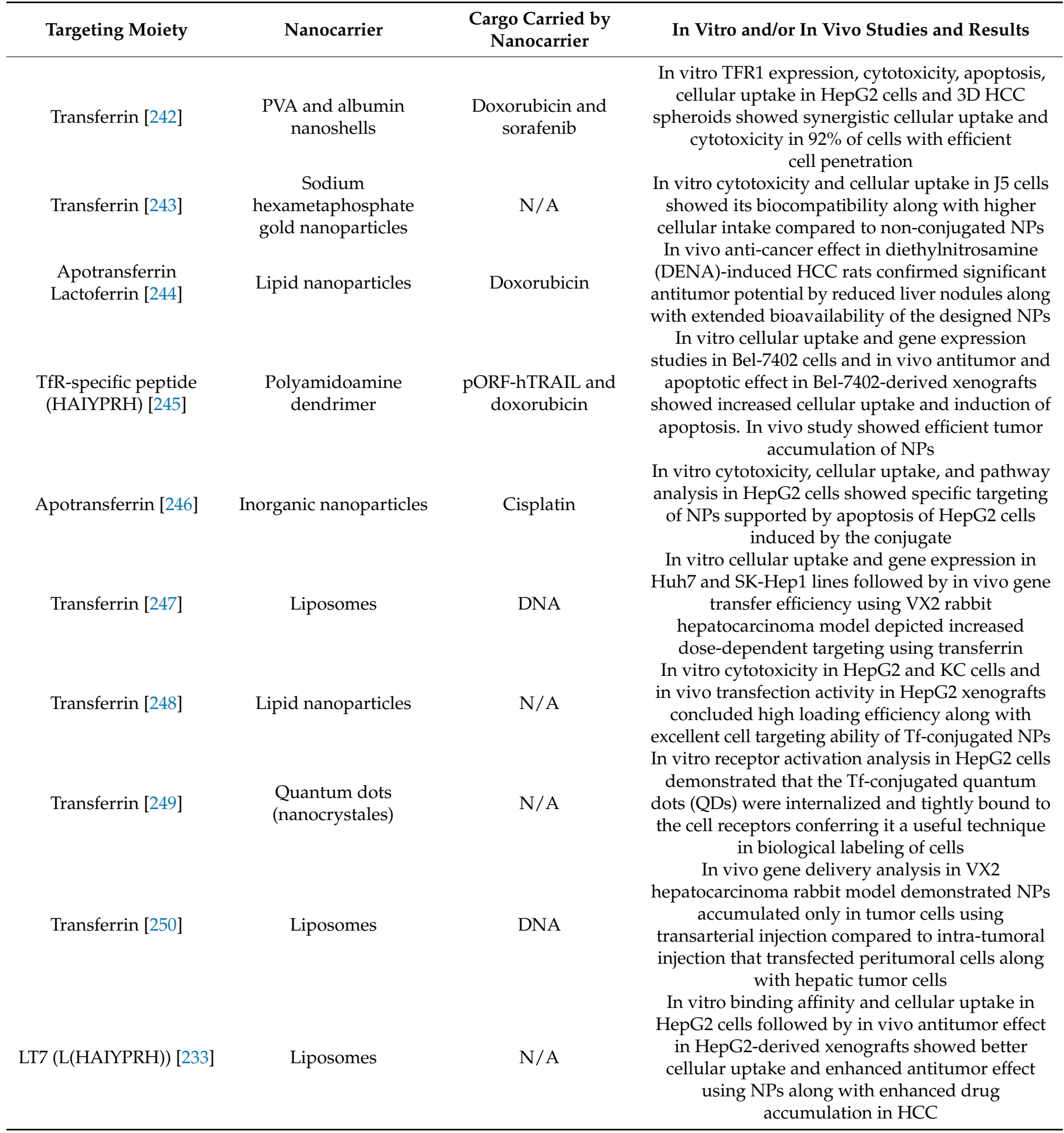




\subsubsection{Folic Acid Receptor (FR)}

The folic acid receptor, a $38 \mathrm{kDa}$ glycosylphos-phatidylinositol membrane-anchored glycoprotein, is overexpressed in several cancers, including HCC (Figure 1) [251-255]. Reports have shown that FR, especially FR- $\alpha$ expression, is significantly increased in malignant tissues with high affinity toward folic acid as compared to normal liver tissues making it an ideal target for drug delivery to the liver $[106,256]$. Folic acid has been used over the past several years as an attractive target to deliver cargo to the liver tissue due to its specificity, small size, stability, non-immunogenic and inexpensive properties $[257,258]$. Mechanistically, folic acid has proven to be vital for fast multiplying cells for DNA synthesis and replication, cell division, growth, and survival, and its deficiency is often associated with abnormal methylation and increased chromosomal strand breaking [259-261]. Therefore, taking advantage of the significant role of folic acid in HCC would provide a promising targeting moiety for nanomedicine. Several studies have used folic acid as a targeting agent in HCC, as shown below (Table 5).

Table 5. Summary of various nanoformulations using folic acid as a potential target to deliver drugs to HCC tumor cells.

\begin{tabular}{|c|c|c|c|}
\hline Targeting Moiety & Nanocarrier & $\begin{array}{l}\text { Cargo Carried by } \\
\text { Nanocarrier }\end{array}$ & In Vitro and/or In Vivo Studies and Results \\
\hline Folic acid [262] & $\begin{array}{l}\text { Pluronic F127 } \\
\text { nanomicelles }\end{array}$ & Silibinin & $\begin{array}{l}\text { In vitro cytotoxicity in HepG2 cells indicated that } \\
\text { the viability of cells treated with conjugated NPs } \\
\text { was significantly less than unconjugated NPs }\end{array}$ \\
\hline Folic acid [263] & $\begin{array}{l}\text { Mn-ZnS quantum } \\
\text { dots with chitosan } \\
\text { biopolymer }\end{array}$ & 5-Fluorouracil & $\begin{array}{l}\text { In vitro drug release and in vivo sub-chronic toxicity } \\
\text { assay and anti-4T1 breast cancer study indicated a } \\
\text { controlled release behavior in vitro and } \\
\text { accumulation of NPs in the tumor of the } \\
\text { tumor-bearing mice }\end{array}$ \\
\hline Folic acid [264] & Casein micelles & Berberine and diosmin & $\begin{array}{c}\text { In vivo cytotoxicity and uptake studies using } \\
\text { HepG2 cells supported with in vivo antitumor } \\
\text { efficacy using DENA-induced HCC mouse model } \\
\text { demonstrated superior cytotoxicity and cellular } \\
\text { uptake in vitro along with increased antitumor } \\
\text { efficacy in vivo }\end{array}$ \\
\hline $\begin{array}{l}\text { Folic acid and/or } \\
\text { bevacizumab (dual } \\
\text { targeting) [265] }\end{array}$ & Carbon dots & $\begin{array}{c}\text { Gadolinium (imaging } \\
\text { nanoprobe) }\end{array}$ & $\begin{array}{l}\text { In vitro cytotoxicity assay, fluorescent imaging, and } \\
\text { cellular uptake using Hepa1-6 and L929 cells } \\
\text { indicated low toxicity with improved sensitivity and } \\
\text { specificity as an ideal fluorophore nanosystem }\end{array}$ \\
\hline Folic acid [266] & $\begin{array}{l}\text { Human serum } \\
\text { albumin } \\
\text { nanoparticles }\end{array}$ & Sorafenib & $\begin{array}{l}\text { In vitro cell viability assay, cellular uptake, and } \\
\text { apoptosis analysis using BEL-7402 cells along with } \\
\text { in vivo antitumor efficacy and safety evaluation and } \\
\text { tissue distribution study using BEL-7402 xenograft } \\
\text { model and pharmacokinetic study confirmed } \\
\text { enhanced cytotoxicity, increased safety, and notably } \\
\text { enhanced sorafenib accumulation in tumor tissues } \\
\text { in vivo }\end{array}$ \\
\hline Folic acid [267] & Quantum dots & 5-fluorouracil & $\begin{array}{l}\text { In vitro cellular uptake using HepG2 cells and } \\
\text { in vivo antitumor efficacy, toxicity, and } \\
\text { biodistribution study using SMMC-7721 xenograft } \\
\text { model indicated reduced cytotoxicity compared to } \\
\text { free drug in vitro and enhanced tumor suppression } \\
\text { in vivo }\end{array}$ \\
\hline Folic acid [268] & ZIF-8 nanoparticles & Doxorubicin & $\begin{array}{l}\text { In vitro cytotoxicity using HepG2 cells showed } \\
\text { higher anti-cancer efficiency as a targeted therapy } \\
\text { In vitro cytotoxicity using SMMC-7721 cell line }\end{array}$ \\
\hline $\begin{array}{l}\text { Folic acid and } \\
\text { Transferrin [269] }\end{array}$ & Graphene oxide DDS & Doxorubicin & $\begin{array}{l}\text { indicated that the double target drug delivery } \\
\text { system exhibited controlled drug release, no toxicity, } \\
\text { and better inhibitory effect on HCC cells }\end{array}$ \\
\hline
\end{tabular}


Table 5. Cont.

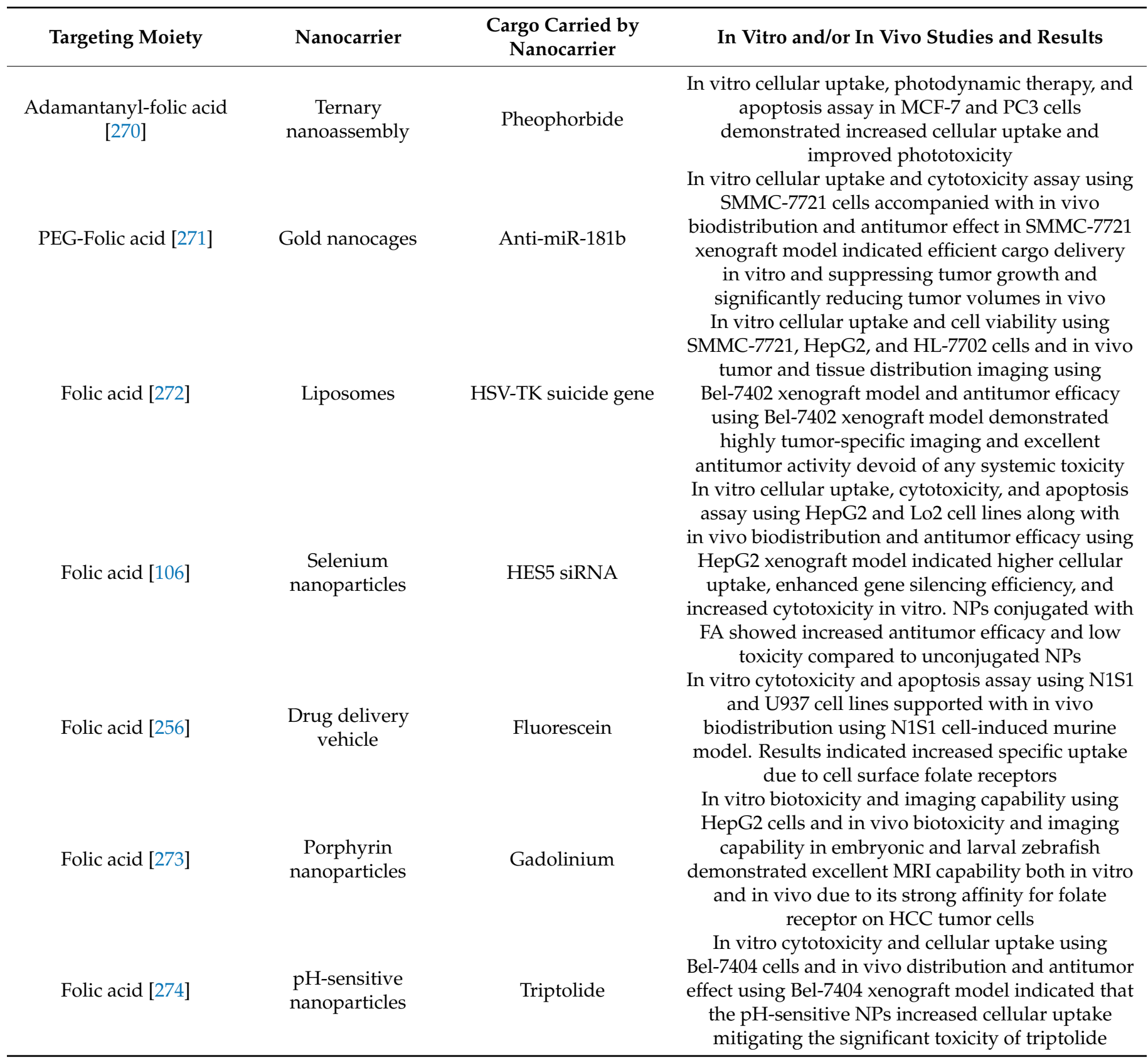

\subsubsection{Scavenger Receptor Class B Type I (SR-B1)}

In addition to various different lipoprotein receptors, SR-B1 is a multiligand membrane receptor protein that possesses ligand properties for cholesterol transport to liver cells (Figure 1). Therefore, SR-B1 plays a central role in cholesterol homeostasis and is a vital element required to maintain cell plasma stability, fluidity, and organization to the liver [275-277]. SR-B1 is broadly overexpressed on hepatocytes and responsible for HDL uptake, making HDL mimics a subject of much interest as a promising, versatile, and efficacious target toward HCC [278-282]. HDLs have consistently drawn attention in targeting HCC due to the increased expression of HDL receptors such as SR-B1 in order to satisfy the tumors' insistent appetite for cholesterol for cell proliferation. Studies have shown HDL targeting using various components of the HDL lifecycle in the liver, whereby LDL is responsible for cholesterol delivery to cells through LDL receptor-mediated endocytosis followed by removal of cholesterol from the periphery and delivering it back to the liver 
for excretion via HDL [283-285]. HDL mimics have shown advantages for nano delivery due to their size and surface properties resembling the native HDL and additionally, protecting them from clearance as compared to other foreign bodies $[275,286]$. Indeed, with its capacity to provide a gateway for delivering therapeutic agents through HDL mimics such as apoA-1, it has found extensive success in various other cancers and therefore has a potential for delivering nanoparticles as selective and specific HCC therapy (Table 6).

Table 6. Brief summary showing the different nanoformulations designed using SR-B1 receptor as a target.

\begin{tabular}{cccc}
\hline Targeting Moiety & Nanocarrier & $\begin{array}{c}\text { Cargo Carried by } \\
\text { Nanocarrier }\end{array}$ & In Vitro and/or In Vivo Studies and Results \\
\hline ApoA-1 [287] & Lipid nanoparticles & SALL4 siRNA & $\begin{array}{c}\text { In vitro cellular uptake assay and silencing efficacy } \\
\text { in KB, HT1080, Hep3B, SNU39, and Huh7 cell lines. } \\
\text { Along with in vivo biodistribution and antitumor } \\
\text { effect in KB, HT1080, and Hep3B xenograft model. } \\
\text { Results showed inhibited tumor growth with a } \\
\text { 3-fold increase in apoptosis }\end{array}$ \\
ApoA-1 [288] & Lipid nanoparticles & Doxorubicin & In vitro cytotoxicity and cellular uptake assay in \\
& Lipid nanoparticles & $\begin{array}{c}\text { HepG2 cells indicated increased cytotoxicity and } \\
\text { cellular uptake in SR-B1-positive liver cells }\end{array}$ & $\begin{array}{c}\text { In vivo imaging, biodistribution, and antitumor } \\
\text { effect in Hepa1-6 xenograft model demonstrated } \\
\text { specific targeting to HCC tumors }\end{array}$ \\
\hline
\end{tabular}

4.2. Emerging Use of Peptides in HCC Therapy as an Evolutionary Improvement in HCC Nanomedicine

With the growing research in search of therapeutic options for HCC, studies have identified proteins that are specifically expressed by tumoral cells. These proteins could be used to generate specific peptides to solve the two major obstacles of tumoral specificity and selectivity in HCC targeting [289]. Peptides, by virtue of their small size, possess a number of unique features defining them as promising therapeutic agents that include effective tissue penetration as well as negligence to the host immune system leading to lesser or no off-target effects and adverse effects [290]. Some of the studied peptides in HCC include SP94 [291-293], Tv1 [294-297], FFW [298,299], iRGD [83,91,300], GG-8-6 [301], BR2 [302,303], 33 [304], GW-H1 [305,306], bovicin HC5 [307], R-Tf-D-LP4 [308], C7 [309], HCC79 [289,310], GPC3 peptide [311-313] and cecropinXJ [290,314]. Peptides are also being investigated in HCC vaccine development, targeting specifically overexpressed targets such as GPC3 [315]. Following completion of a Phase 1 study of a GPC3 targeting peptide, it was further concluded that the antitumor effects of the peptide alone could not be significant enough, and therefore, the future prospects would be to develop combinational therapies [315]. Therefore, the future lies in using peptides as a targeting modality in drug-encapsulated nanoformulations as a combinational therapy that could make up for the relatively low affinity of peptides and improve antitumor activity.

\subsection{Nanomedicine as a Vehicle for Delivery of Chemotherapy and siRNA into HCC Cells}

Overall, the summary of the nanoparticle literature above provides insight into the variety of intracellular targets that have been targeted with chemotherapeutic agents or siRNA as cargo with nanoparticles as the vehicle for delivery. The nanoparticles facilitate endocytosis of the cargo into the HCC cells. Chemotherapeutic agents encapsulated into nanoparticles have included doxorubicin, paclitaxel, docetaxel, sorafenib, 5-fluoruracil, and gemcitabine. This approach was shown to increase retention time within the tumor cells and effectively inhibit tumor growth in preclinical models of HCC. The single interference RNA approach has also been leveraged in combination with nanoparticles for the treatment of HCC in preclinical models. Some of the targeted genes include survivin, SALL4 and cyclin E [316], NET-1 [317], EMS1 [317], COP9, VEGF [317,318], Bmi1 [140], midkine [319], 
livin [320,321], c-Myc [322,323], p28GANK [324], CXCR4 [325], DP-1 [134], and integrin B1 [133,326-331]. Beyond specific genes, the targeting of a specific miRNA with the siRNA approach has also been evaluated in preclinical models; for example, miRNA-21, miRNA320a, miRNA-101, and miRNA-122 were preferably taken up by hepatocytes and the tumor cells, further demonstrating a decrease in tumor burden [322,332-334].

\section{Conclusions}

The cutting-edge research and development in HCC nanomedicine have provided a powerful tool over traditional approaches for specific tumor targeting. Although designing a nano-drug delivery system is a complex process that requires optimization of its physicochemical properties, targeting HCC cells also requires a thorough understanding of the challenges such as a cirrhotic liver setting and the interaction between nanoparticles and the HCC tumor environment hindering its transition to clinical practice. There are several significant advantages of nanotechnology, ranging from effective targeting to reduced systemic toxicity. Currently, the only FDA-approved nanomedicine for various other cancer treatments includes; Doxil (liposomal doxorubicin), Onivyde (liposomal irinotecan), Abraxane (albumin-particle bound paclitaxel), Eligard (leuprolide acetate), and Vyxeos (liposomal cytarabine and daunorubicin) with none specific to HCC. Interestingly, the most crucial part of designing HCC nanomedicine requires formulating nano systems with ligands specific to the receptors discussed above, such as ASGPR, GPC3, TfR, FR, and SR-B1. Nano systems with such targeting ligands have proven their efficacy for anti-cancer treatment in several in vitro and in vivo studies. Therefore, there has been progressive development in specific targeted nano delivery systems for HCC, and there is excellent potential for translation of this strategy into the clinical context.

Author Contributions: Conceptualization, A.B., G.Z., M.B.; Writing, A.B.; Review and editing, G.Z. and M.B.; Funding acquisition, M.B. All authors have read and agreed to the published version of the manuscript.

Funding: This project is funded by the Canadian Liver Foundation and the Toronto General and Western Hospital Foundation. A.B. is externally funded by a Mitacs Elevate postdoctoral fellowship in collaboration with Highland Therapeutics Ltd., Toronto, ON, Canada.

Institutional Review Board Statement: Not applicable.

Informed Consent Statement: Not applicable.

Conflicts of Interest: The authors declare no conflict of interest.

\section{References}

1. Wong, C.-M.; Tsang, F.H.-C.; Ng, I.O.-L. Non-coding RNAs in hepatocellular carcinoma: Molecular functions and pathological implications. Nat. Rev. Gastroenterol. Hepatol. 2018, 15, 137. [CrossRef] [PubMed]

2. Dhanasekaran, R.; Limaye, A.; Cabrera, R. Hepatocellular carcinoma: Current trends in worldwide epidemiology, risk factors, diagnosis, and therapeutics. Hepatic Med. Evid. Res. 2012, 4, 19.

3. Nault, J.-C.; Datta, S.; Imbeaud, S.; Franconi, A.; Mallet, M.; Couchy, G.; Letouzé, E.; Pilati, C.; Verret, B.; Blanc, J.-F. Recurrent AAV2-related insertional mutagenesis in human hepatocellular carcinomas. Nat. Genet. 2015, 47, 1187-1193. [CrossRef] [PubMed]

4. Kew, M.C. Aflatoxins as a cause of hepatocellular carcinoma. J. Gastrointest. Liver Dis. 2013, 22, 305-310.

5. Magnussen, A.; Parsi, M.A. Aflatoxins, hepatocellular carcinoma and public health. World J. Gastroenterol. 2013, 19, 1508. [CrossRef] [PubMed]

6. Wu, H.C.; Santella, R. The role of aflatoxins in hepatocellular carcinoma. Hepat. Mon. 2012, 12, e7238. [CrossRef]

7. Zhou, Y.-Y.; Zhu, G.-Q.; Liu, T.; Zheng, J.-N.; Cheng, Z.; Zou, T.-T.; Braddock, M.; Fu, S.-W.; Zheng, M.-H. Systematic review with network meta-analysis: Antidiabetic medication and risk of hepatocellular carcinoma. Sci. Rep. 2016, 6, 33743. [CrossRef]

8. Kawaguchi, T.; Taniguchi, E.; Morita, Y.; Shirachi, M.; Tateishi, I.; Nagata, E.; Sata, M. Association of exogenous insulin or sulphonylurea treatment with an increased incidence of hepatoma in patients with hepatitis C virus infection. Liver Int. 2010, 30, 479-486. [CrossRef]

9. Singh, S.; Singh, P.P.; Singh, A.G.; Murad, M.H.; Sanchez, W. Anti-diabetic medications and the risk of hepatocellular cancer: A systematic review and meta-analysis. Off. J. Am. Coll. Gastroenterol. 2013, 108, 881-891. [CrossRef]

10. Chen, H.-P.; Shieh, J.-J.; Chang, C.-C.; Chen, T.-T.; Lin, J.-T.; Wu, M.-S.; Lin, J.-H.; Wu, C.-Y. Metformin decreases hepatocellular carcinoma risk in a dose-dependent manner: Population-based and in vitro studies. Gut 2013, 62, 606-615. [CrossRef] [PubMed] 
11. Donadon, V.; Balbi, M.; Mas, M.D.; Casarin, P.; Zanette, G. Metformin and reduced risk of hepatocellular carcinoma in diabetic patients with chronic liver disease. Liver Int. 2010, 30, 750-758. [CrossRef]

12. Kramer, J.R.; Natarajan, Y.; Dai, J.; Yu, X.; Li, L.; El-Serag, H.; Kanwal, F. Effect of diabetes medications and glycemic control on risk of hepatocellular cancer in patients with non-alcoholic fatty liver disease. Hepatology 2021, 1-9. [CrossRef]

13. Chang, C.H.; Lin, J.W.; Wu, L.C.; Lai, M.S.; Chuang, L.M.; Chan, K.A. Association of thiazolidinediones with liver cancer and colorectal cancer in type 2 diabetes mellitus. Hepatology 2012, 55, 1462-1472. [CrossRef] [PubMed]

14. Hsiang, J.C.; Wong, G.L.-H.; Tse, Y.-K.; Wong, V.W.-S.; Yip, T.C.-F.; Chan, H.L.-Y. Statin and the risk of hepatocellular carcinoma and death in a hospital-based hepatitis B-infected population: A propensity score landmark analysis. J. Hepatol. 2015, 63, 1190-1197. [CrossRef] [PubMed]

15. Singh, S.; Singh, P.P.; Singh, A.G.; Murad, M.H.; Sanchez, W. Statins are associated with a reduced risk of hepatocellular cancer: A systematic review and meta-analysis. Gastroenterology 2013, 144, 323-332. [CrossRef] [PubMed]

16. Simon, T.G.; Ma, Y.; Ludvigsson, J.F.; Chong, D.Q.; Giovannucci, E.L.; Fuchs, C.S.; Meyerhardt, J.A.; Corey, K.E.; Chung, R.T.; Zhang, X. Association between aspirin use and risk of hepatocellular carcinoma. JAMA Oncol. 2018, 4, 1683-1690. [CrossRef] [PubMed]

17. Kao, W.Y.; Su, C.W.; Chia-Hui Tan, E.; Lee, P.C.; Chen, P.H.; Tang, J.H.; Huang, Y.H.; Huo, T.I.; Chang, C.C.; Hou, M.C. Proton pump inhibitors and risk of hepatocellular carcinoma in patients with chronic hepatitis B or C. Hepatology 2019, 69, 1151-1164. [CrossRef]

18. Lau, W.-y.; Leung, T.W.; Lai, B.-s.; Liew, C.-t.; Ho, S.K.; Yu, S.C.; Tang, A.M. Preoperative systemic chemoimmunotherapy and sequential resection for unresectable hepatocellular carcinoma. Ann. Surg. 2001, 233, 236. [CrossRef] [PubMed]

19. Raoul, J.-L.; Forner, A.; Bolondi, L.; Cheung, T.T.; Kloeckner, R.; de Baere, T. Updated use of TACE for hepatocellular carcinoma treatment: How and when to use it based on clinical evidence. Cancer Treat. Rev. 2019, 72, 28-36. [CrossRef] [PubMed]

20. Kudo, M. Systemic therapy for hepatocellular carcinoma: Latest advances. Cancers 2018, 10, 412. [CrossRef]

21. Marisi, G.; Cucchetti, A.; Ulivi, P.; Canale, M.; Cabibbo, G.; Solaini, L.; Foschi, F.G.; De Matteis, S.; Ercolani, G.; Valgiusti, M. Ten years of sorafenib in hepatocellular carcinoma: Are there any predictive and/or prognostic markers? World J. Gastroenterol. 2018, 24, 4152. [CrossRef]

22. Llovet, J.M.; Ricci, S.; Mazzaferro, V.; Hilgard, P.; Gane, E.; Blanc, J.-F.; De Oliveira, A.C.; Santoro, A.; Raoul, J.-L.; Forner, A. Sorafenib in advanced hepatocellular carcinoma. N. Engl. J. Med. 2008, 359, 378-390. [CrossRef]

23. Wilhelm, S.M.; Carter, C.; Tang, L.; Wilkie, D.; McNabola, A.; Rong, H.; Chen, C.; Zhang, X.; Vincent, P.; McHugh, M. BAY 43-9006 exhibits broad spectrum oral antitumor activity and targets the RAF/MEK/ERK pathway and receptor tyrosine kinases involved in tumor progression and angiogenesis. Cancer Res. 2004, 64, 7099-7109. [CrossRef] [PubMed]

24. Chang, Y.S.; Adnane, J.; Trail, P.A.; Levy, J.; Henderson, A.; Xue, D.; Bortolon, E.; Ichetovkin, M.; Chen, C.; McNabola, A. Sorafenib (BAY 43-9006) inhibits tumor growth and vascularization and induces tumor apoptosis and hypoxia in RCC xenograft models. Cancer Chemother. Pharmacol. 2007, 59, 561-574. [CrossRef]

25. Raoul, J.-L.; Frenel, J.-S.; Raimbourg, J.; Gilabert, M. Current options and future possibilities for the systemic treatment of hepatocellular carcinoma. Hepatic Oncol. 2019, 6, HEP11. [CrossRef] [PubMed]

26. Kudo, M.; Finn, R.S.; Qin, S.; Han, K.-H.; Ikeda, K.; Piscaglia, F.; Baron, A.; Park, J.-W.; Han, G.; Jassem, J. Lenvatinib versus sorafenib in first-line treatment of patients with unresectable hepatocellular carcinoma: A randomised phase 3 non-inferiority trial. Lancet 2018, 391, 1163-1173. [CrossRef]

27. Ikeda, K.; Kudo, M.; Kawazoe, S.; Osaki, Y.; Ikeda, M.; Okusaka, T.; Tamai, T.; Suzuki, T.; Hisai, T.; Hayato, S. Phase 2 study of lenvatinib in patients with advanced hepatocellular carcinoma. J. Gastroenterol. 2017, 52, 512-519. [CrossRef] [PubMed]

28. Kudo, M. Lenvatinib in advanced hepatocellular carcinoma. Liver Cancer 2017, 6, 253-263. [CrossRef]

29. Bruix, J.; Tak, W.-Y.; Gasbarrini, A.; Santoro, A.; Colombo, M.; Lim, H.-Y.; Mazzaferro, V.; Wiest, R.; Reig, M.; Wagner, A. Regorafenib as second-line therapy for intermediate or advanced hepatocellular carcinoma: Multicentre, open-label, phase II safety study. Eur. J. Cancer 2013, 49, 3412-3419. [CrossRef]

30. Kelley, R.; Verslype, C.; Cohn, A.; Yang, T.-S.; Su, W.-C.; Burris, H.; Braiteh, F.; Vogelzang, N.; Spira, A.; Foster, P. Cabozantinib in hepatocellular carcinoma. Cabozantinib in hepatocellular carcinoma: Results of a phase 2 placebo-controlled randomized discontinuation study. Ann. Oncol. 2017, 28, 528-534. [CrossRef]

31. Lee, M.; Ryoo, B.-Y.; Hsu, C.-H.; Numata, K.; Stein, S.; Verret, W.; Hack, S.; Spahn, J.; Liu, B.; Abdullah, H. Randomised efficacy and safety results for atezolizumab (Atezo)+ bevacizumab (Bev) in patients (pts) with previously untreated, unresectable hepatocellular carcinoma (HCC). Ann. Oncol. 2019, 30, v875. [CrossRef]

32. Finn, R.S.; Qin, S.; Ikeda, M.; Galle, P.R.; Ducreux, M.; Kim, T.-Y.; Kudo, M.; Breder, V.; Merle, P.; Kaseb, A.O. Atezolizumab plus bevacizumab in unresectable hepatocellular carcinoma. N. Engl. J. Med. 2020, 382, 1894-1905. [CrossRef]

33. Herbst, R.S.; Soria, J.-C.; Kowanetz, M.; Fine, G.D.; Hamid, O.; Gordon, M.S.; Sosman, J.A.; McDermott, D.F.; Powderly, J.D.; Gettinger, S.N. Predictive correlates of response to the anti-PD-L1 antibody MPDL3280A in cancer patients. Nature 2014, 515, 563-567. [CrossRef]

34. Ferrara, N.; Hillan, K.J.; Novotny, W. Bevacizumab (Avastin), a humanized anti-VEGF monoclonal antibody for cancer therapy. Biochem. Biophys. Res. Commun. 2005, 333, 328-335. [CrossRef] 
35. Finn, R.S.; Bentley, G.; Britten, C.D.; Amado, R.; Busuttil, R.W. Targeting vascular endothelial growth factor with the monoclonal antibody bevacizumab inhibits human hepatocellular carcinoma cells growing in an orthotopic mouse model. Liver Int. 2009, 29, 284-290. [CrossRef] [PubMed]

36. Citterio, D.; Facciorusso, A.; Sposito, C.; Rota, R.; Bhoori, S.; Mazzaferro, V. Hierarchic interaction of factors associated with liver decompensation after resection for hepatocellular carcinoma. JAMA Surg. 2016, 151, 846-853. [CrossRef] [PubMed]

37. Huang, A.C.; Postow, M.A.; Orlowski, R.J.; Mick, R.; Bengsch, B.; Manne, S.; Xu, W.; Harmon, S.; Giles, J.R.; Wenz, B. T-cell invigoration to tumour burden ratio associated with anti-PD-1 response. Nature 2017, 545, 60-65. [CrossRef] [PubMed]

38. Swartz, M.; Hirosue, S.; Hubbell, J. Engineering approaches to immunotherapy. Sci. Transl. Med. 2012, 4, 148rv9. [CrossRef] [PubMed]

39. Ferrari, M. Cancer nanotechnology: Opportunities and challenges. Nat. Rev. Cancer 2005, 5, 161-171. [CrossRef]

40. Ren, Z.; Chen, X.; Hong, L.; Zhao, X.; Cui, G.; Li, A.; Liu, Y.; Zhou, L.; Sun, R.; Shen, S. Nanoparticle conjugation of ginsenoside Rg3 inhibits hepatocellular carcinoma development and metastasis. Small 2020, 16, 1905233. [CrossRef]

41. Peer, D.; Karp, J.M.; Hong, S.; Farokhzad, O.C.; Margalit, R.; Langer, R. Nanocarriers as an emerging platform for cancer therapy. Nat. Nanotechnol. 2007, 2, 751-760. [CrossRef] [PubMed]

42. Kearney, C.J.; Mooney, D.J. Macroscale delivery systems for molecular and cellular payloads. Nat. Mater. 2013, 12, 1004-1017. [CrossRef] [PubMed]

43. Shi, J.; Kantoff, P.W.; Wooster, R.; Farokhzad, O.C. Cancer nanomedicine: Progress, challenges and opportunities. Nat. Rev. Cancer 2017, 17, 20. [CrossRef] [PubMed]

44. Min, Y.; Roche, K.C.; Tian, S.; Eblan, M.J.; McKinnon, K.P.; Caster, J.M.; Chai, S.; Herring, L.E.; Zhang, L.; Zhang, T. Antigencapturing nanoparticles improve the abscopal effect and cancer immunotherapy. Nat. Nanotechnol. 2017, 12, 877. [CrossRef] [PubMed]

45. Pranatharthiharan, S.; Patel, M.D.; Malshe, V.C.; Pujari, V.; Gorakshakar, A.; Madkaikar, M.; Ghosh, K.; Devarajan, P.V. Asialoglycoprotein receptor targeted delivery of doxorubicin nanoparticles for hepatocellular carcinoma. Drug Deliv. 2017, 24, 20-29. [CrossRef]

46. Taniguchi, N. On the basic concept of nanotechnology. In Proceedings of the International Conference on Production Engineering, Tokyo, Japan, 26-29 August 1974.

47. Mintz, K.J.; Leblanc, R.M. The use of nanotechnology to combat liver cancer: Progress and perspectives. Biochim. Biophys. Acta Rev. Cancer 2021, 1876, 188621. [CrossRef]

48. Blanco, E.; Shen, H.; Ferrari, M. Principles of nanoparticle design for overcoming biological barriers to drug delivery. Nat. Biotechnol. 2015, 33, 941-951. [CrossRef] [PubMed]

49. Gao, Y.; Hu, L.; Liu, Y.; Xu, X.; Wu, C. Targeted delivery of paclitaxel in liver cancer using hyaluronic acid functionalized mesoporous hollow alumina nanoparticles. BioMed Res. Int. 2019, 2019, 2928507. [CrossRef] [PubMed]

50. Hu, J.; Dong, Y.; Ding, L.; Dong, Y.; Wu, Z.; Wang, W.; Shen, M.; Duan, Y. Local delivery of arsenic trioxide nanoparticles for hepatocellular carcinoma treatment. Signal Transduct. Target. Ther. 2019, 4, 28. [CrossRef]

51. Huang, Y.; Zhou, B.; Luo, H.; Mao, J.; Huang, Y.; Zhang, K.; Mei, C.; Yan, Y.; Jin, H.; Gao, J. ZnAs@ SiO² nanoparticles as a potential anti-tumor drug for targeting stemness and epithelial-mesenchymal transition in hepatocellular carcinoma via SHP-1/JAK2/STAT3 signaling. Theranostics 2019, 9, 4391. [CrossRef]

52. Chi, X.; Zhang, R.; Zhao, T.; Gong, X.; Wei, R.; Yin, Z.; Lin, H.; Li, D.; Shan, H.; Gao, J. Targeted arsenite-loaded magnetic multifunctional nanoparticles for treatment of hepatocellular carcinoma. Nanotechnology 2019, 30, 175101. [CrossRef] [PubMed]

53. $\mathrm{Wu}, \mathrm{C}$; Gao, Y.; Liu, Y.; Xu, X. Pure paclitaxel nanoparticles: Preparation, characterization, and antitumor effect for human liver cancer SMMC-7721 cells. Int. J. Nanomed. 2018, 13, 6189. [CrossRef]

54. Zhang, N.-n.; Lu, C.-y.; Shu, G.-f.; Li, J.; Chen, M.-j.; Chen, C.-m.; Lv, X.-1.; Xu, X.-1.; Weng, W.; Weng, Q.-y. Gadolinium-loaded calcium phosphate nanoparticles for magnetic resonance imaging of orthotopic hepatocarcinoma and primary hepatocellular carcinoma. Biomater. Sci. 2020, 8, 1961-1972. [CrossRef] [PubMed]

55. Wu, J.-Y.; Wang, Z.-X.; Zhang, G.; Lu, X.; Qiang, G.-H.; Hu, W.; Ji, A.-L.; Wu, J.-H.; Jiang, C.-P. Targeted co-delivery of Beclin 1 siRNA and FTY720 to hepatocellular carcinoma by calcium phosphate nanoparticles for enhanced anticancer efficacy. Int. J. Nanomed. 2018, 13, 1265. [CrossRef] [PubMed]

56. Zhao, P.; Li, M.; Wang, Y.; Chen, Y.; He, C.; Zhang, X.; Yang, T.; Lu, Y.; You, J.; Lee, R.J. Enhancing anti-tumor efficiency in hepatocellular carcinoma through the autophagy inhibition by miR-375/sorafenib in lipid-coated calcium carbonate nanoparticles. Acta Biomater. 2018, 72, 248-255. [CrossRef] [PubMed]

57. Zhao, P.; Wu, S.; Cheng, Y.; You, J.; Chen, Y.; Li, M.; He, C.; Zhang, X.; Yang, T.; Lu, Y. MiR-375 delivered by lipid-coated doxorubicin-calcium carbonate nanoparticles overcomes chemoresistance in hepatocellular carcinoma. Nanomed. Nanotechnol. Biol. Med. 2017, 13, 2507-2516. [CrossRef] [PubMed]

58. Zhang, Y.-Q.; Shen, Y.; Liao, M.-M.; Mao, X.; Mi, G.-J.; You, C.; Guo, Q.-Y.; Li, W.-J.; Wang, X.-Y.; Lin, N. Galactosylated chitosan triptolide nanoparticles for overcoming hepatocellular carcinoma: Enhanced therapeutic efficacy, low toxicity, and validated network regulatory mechanisms. Nanomed. Nanotechnol. Biol. Med. 2019, 15, 86-97. [CrossRef]

59. Tang, P.; Sun, Q.; Yang, H.; Tang, B.; Pu, H.; Li, H. Honokiol nanoparticles based on epigallocatechin gallate functionalized chitin to enhance therapeutic effects against liver cancer. Int. J. Pharm. 2018, 545, 74-83. [CrossRef] 
60. Cheng, M.; Zhu, W.; Li, Q.; Dai, D.; Hou, Y. Anti-cancer efficacy of biotinylated chitosan nanoparticles in liver cancer. Oncotarget 2017, 8, 59068. [CrossRef]

61. Kou, C.H.; Han, J.; Han, X.L.; Zhuang, H.J.; Zhao, Z.M. Preparation and characterization of the Adriamycin-loaded amphiphilic chitosan nanoparticles and their application in the treatment of liver cancer. Oncol. Lett. 2017, 14, 7833-7841. [CrossRef]

62. Loutfy, S.A.; El-Din, H.M.A.; Elberry, M.H.; Allam, N.G.; Hasanin, M.; Abdellah, A.M. Synthesis, characterization and cytotoxic evaluation of chitosan nanoparticles: In vitro liver cancer model. Adv. Nat. Sci. Nanosci. Nanotechnol. 2016, 7, 035008. [CrossRef]

63. Choi, K.; Joo, H. Assessment of gold nanoparticles-inhibited cytochrome P450 3A4 activity and molecular mechanisms underlying its cellular toxicity in human hepatocellular carcinoma cell line C3A. Nanoscale Res. Lett. 2018, 13, 279. [CrossRef]

64. Salem, D.S.; Sliem, M.A.; El-Sesy, M.; Shouman, S.A.; Badr, Y. Improved chemo-photothermal therapy of hepatocellular carcinoma using chitosan-coated gold nanoparticles. J. Photochem. Photobiol. B Biol. 2018, 182, 92-99. [CrossRef] [PubMed]

65. Khandanlou, R.; Murthy, V.; Saranath, D.; Damani, H. Synthesis and characterization of gold-conjugated Backhousia citriodora nanoparticles and their anticancer activity against MCF-7 breast and HepG2 liver cancer cell lines. J. Mater. Sci. 2018, 53, 3106-3118. [CrossRef]

66. Guo, M.; Sun, Y.; Zhang, X.-D. Enhanced radiation therapy of gold nanoparticles in liver cancer. Appl. Sci. 2017, 7, 232. [CrossRef]

67. Xue, H.-Y.; Liu, Y.; Liao, J.-Z.; Lin, J.-S.; Li, B.; Yuan, W.-G.; Lee, R.J.; Li, L.; Xu, C.-R.; He, X.-X. Gold nanoparticles delivered miR-375 for treatment of hepatocellular carcinoma. Oncotarget 2016, 7, 86675. [CrossRef] [PubMed]

68. Jha, S.; Ramadori, F.; Quarta, S.; Biasiolo, A.; Fabris, E.; Baldan, P.; Guarino, G.; Ruvoletto, M.; Villano, G.; Turato, C. Binding and uptake into human hepatocellular carcinoma cells of peptide-functionalized gold nanoparticles. Bioconjugate Chem. 2017, 28, 222-229. [CrossRef] [PubMed]

69. Rajeshkumar, S. Anticancer activity of eco-friendly gold nanoparticles against lung and liver cancer cells. J. Genet. Eng. Biotechnol. 2016, 14, 195-202. [CrossRef] [PubMed]

70. Shaat, H.; Mostafa, A.; Moustafa, M.; Gamal-Eldeen, A.; Emam, A.; El-Hussieny, E.; Elhefnawi, M. Modified gold nanoparticles for intracellular delivery of anti-liver cancer siRNA. Int. J. Pharm. 2016, 504, 125-133. [CrossRef] [PubMed]

71. Ma, X.; Hui, H.; Jin, Y.; Dong, D.; Liang, X.; Yang, X.; Tan, K.; Dai, Z.; Cheng, Z.; Tian, J. Enhanced immunotherapy of SM5-1 in hepatocellular carcinoma by conjugating with gold nanoparticles and its in vivo bioluminescence tomographic evaluation. Biomaterials 2016, 87, 46-56. [CrossRef]

72. Mocan, L.; Matea, C.; Tabaran, F.A.; Mosteanu, O.; Pop, T.; Mocan, T.; Iancu, C. Photothermal treatment of liver cancer with albumin-conjugated gold nanoparticles initiates Golgi Apparatus-ER dysfunction and caspase-3 apoptotic pathway activation by selective targeting of Gp60 receptor. Int. J. Nanomed. 2015, 10, 5435.

73. Tomuleasa, C.; Soritau, O.; Orza, A.; Dudea, M.; Petrushev, B.; Mosteanu, O.; Susman, S.; Florea, A.; Pall, E.; Aldea, M. Gold nanoparticles conjugated with cisplatin/doxorubicin/capecitabine lower the chemoresistance of hepatocellular carcinomaderived cancer cells. J. Gastrointest. Liver Dis. 2012, 21, 186-196.

74. Pracht, M.; Chajon, E.; de Baere, T.; Nguyen, F.; Bronowicki, J.-P.; Vendrely, V.; Baumann, A.-S.; Croise-Laurent, V.; Rio, E.; Rolland, Y. Hepatocellular carcinoma and liver metastasis treated by hafnium oxide nanoparticles activated by stereotactic body radiation therapy. Ann. Oncol. 2018, 29, viii240. [CrossRef]

75. Lunov, O.; Uzhytchak, M.; Smolková, B.; Lunova, M.; Jirsa, M.; Dempsey, N.M.; Dias, A.L.; Bonfim, M.; Hof, M.; Jurkiewicz, P. Remote actuation of apoptosis in liver cancer cells via magneto-mechanical modulation of iron oxide nanoparticles. Cancers 2019, 11, 1873. [CrossRef] [PubMed]

76. Yang, Z.; Duan, J.; Wang, J.; Liu, Q.; Shang, R.; Yang, X.; Lu, P.; Xia, C.; Wang, L.; Dou, K. Superparamagnetic iron oxide nanoparticles modified with polyethylenimine and galactose for siRNA targeted delivery in hepatocellular carcinoma therapy. Int. J. Nanomed. 2018, 13, 1851. [CrossRef]

77. Kandasamy, G.; Sudame, A.; Luthra, T.; Saini, K.; Maity, D. Functionalized hydrophilic superparamagnetic iron oxide nanoparticles for magnetic fluid hyperthermia application in liver cancer treatment. Am. Chem. Soc. Omega 2018, 3, 3991-4005. [CrossRef] [PubMed]

78. Liang, J.; Zhang, X.; Miao, Y.; Li, J.; Gan, Y. Lipid-coated iron oxide nanoparticles for dual-modal imaging of hepatocellular carcinoma. Int. J. Nanomed. 2017, 12, 2033. [CrossRef] [PubMed]

79. Depalo, N.; Iacobazzi, R.M.; Valente, G.; Arduino, I.; Villa, S.; Canepa, F.; Laquintana, V.; Fanizza, E.; Striccoli, M.; Cutrignelli, A. Sorafenib delivery nanoplatform based on superparamagnetic iron oxide nanoparticles magnetically targets hepatocellular carcinoma. Nano Res. 2017, 10, 2431-2448. [CrossRef]

80. Maeng, J.H.; Lee, D.-H.; Jung, K.H.; Bae, Y.-H.; Park, I.-S.; Jeong, S.; Jeon, Y.-S.; Shim, C.-K.; Kim, W.; Kim, J. Multifunctional doxorubicin loaded superparamagnetic iron oxide nanoparticles for chemotherapy and magnetic resonance imaging in liver cancer. Biomaterials 2010, 31, 4995-5006. [CrossRef] [PubMed]

81. Zhao, H.; Wu, M.; Zhu, L.; Tian, Y.; Wu, M.; Li, Y.; Deng, L.; Jiang, W.; Shen, W.; Wang, Z. Cell-penetrating peptide-modified targeted drug-loaded phase-transformation lipid nanoparticles combined with low-intensity focused ultrasound for precision theranostics against hepatocellular carcinoma. Theranostics 2018, 8, 1892. [CrossRef] [PubMed]

82. Wu, C.-H.; Lan, C.-H.; Wu, K.-L.; Wu, Y.M.; Jane, W.-N.; Hsiao, M.; Wu, H.-C. Hepatocellular carcinoma-targeted nanoparticles for cancer therapy. Int. J. Oncol. 2018, 52, 389-401. [CrossRef] [PubMed] 
83. Zhang, J.; Hu, J.; Chan, H.F.; Skibba, M.; Liang, G.; Chen, M. iRGD decorated lipid-polymer hybrid nanoparticles for targeted co-delivery of doxorubicin and sorafenib to enhance anti-hepatocellular carcinoma efficacy. Nanomed. Nanotechnol. Biol. Med. 2016, 12, 1303-1311. [CrossRef] [PubMed]

84. Zhao, X.; Chen, Q.; Liu, W.; Li, Y.; Tang, H.; Liu, X.; Yang, X. Codelivery of doxorubicin and curcumin with lipid nanoparticles results in improved efficacy of chemotherapy in liver cancer. Int. J. Nanomed. 2015, 10, 257.

85. Tang, X.; Chen, L.; Li, A.; Cai, S.; Zhang, Y.; Liu, X.; Jiang, Z.; Liu, X.; Liang, Y.; Ma, D. Anti-GPC3 antibody-modified sorafenibloaded nanoparticles significantly inhibited HepG2 hepatocellular carcinoma. Drug Deliv. 2018, 25, 1484-1494. [CrossRef] [PubMed]

86. Wang, Q.; Zhang, X.; Liao, H.; Sun, Y.; Ding, L.; Teng, Y.; Zhu, W.H.; Zhang, Z.; Duan, Y. Multifunctional shell-core nanoparticles for treatment of multidrug resistance hepatocellular carcinoma. Adv. Funct. Mater. 2018, 28, 1706124. [CrossRef]

87. Zheng, N.; Liu, W.; Li, B.; Nie, H.; Liu, J.; Cheng, Y.; Wang, J.; Dong, H.; Jia, L. Co-delivery of sorafenib and metapristone encapsulated by CXCR4-targeted PLGA-PEG nanoparticles overcomes hepatocellular carcinoma resistance to sorafenib. J. Exp. Clin. Cancer Res. 2019, 38, 232. [CrossRef] [PubMed]

88. Wang, H.; Zhou, L.; Xie, K.; Wu, J.; Song, P.; Xie, H.; Zhou, L.; Liu, J.; Xu, X.; Shen, Y. Polylactide-tethered prodrugs in polymeric nanoparticles as reliable nanomedicines for the efficient eradication of patient-derived hepatocellular carcinoma. Theranostics 2018, 8, 3949. [CrossRef] [PubMed]

89. Qin, J.-M.; Yin, P.-H.; Li, Q.; Sa, Z.-Q.; Sheng, X.; Yang, L.; Huang, T.; Zhang, M.; Gao, K.-P.; Chen, Q.-H. Anti-tumor effects of brucine immuno-nanoparticles on hepatocellular carcinoma. Int. J. Nanomed. 2012, 7, 369. [CrossRef]

90. Qin, J.; Yang, L.; Sheng, X.; Sa, Z.; Huang, T.; Li, Q.; Gao, K.; Chen, Q.; Ma, J.; Shen, H. Antitumor effects of brucine immunonanoparticles on hepatocellular carcinoma in vivo. Oncol. Lett. 2018, 15, 6137-6146. [CrossRef]

91. Wang, J.; Wang, H.; Li, J.; Liu, Z.; Xie, H.; Wei, X.; Lu, D.; Zhuang, R.; Xu, X.; Zheng, S. iRGD-decorated polymeric nanoparticles for the efficient delivery of vandetanib to hepatocellular carcinoma: Preparation and in vitro and in vivo evaluation. Am. Chem. Soc. Appl. Mater. Interfaces 2016, 8, 19228-19237. [CrossRef] [PubMed]

92. Liu, H.; Gao, M.; Xu, H.; Guan, X.; Lv, L.; Deng, S.; Zhang, C.; Tian, Y. A promising emodin-loaded poly (lactic-co-glycolic acid)-d- $\alpha$-tocopheryl polyethylene glycol 1000 succinate nanoparticles for liver cancer therapy. Pharm. Res. 2016, 33, 217-236. [CrossRef]

93. Zhu, D.; Tao, W.; Zhang, H.; Liu, G.; Wang, T.; Zhang, L.; Zeng, X.; Mei, L. Docetaxel (DTX)-loaded polydopamine-modified TPGS-PLA nanoparticles as a targeted drug delivery system for the treatment of liver cancer. Acta Biomater. 2016, 30, 144-154. [CrossRef] [PubMed]

94. Liu, Y.; Chen, Z.; Liu, C.; Yu, D.; Lu, Z.; Zhang, N. Gadolinium-loaded polymeric nanoparticles modified with Anti-VEGF as multifunctional MRI contrast agents for the diagnosis of liver cancer. Biomaterials 2011, 32, 5167-5176. [CrossRef] [PubMed]

95. Shoshan, M.S.; Vonderach, T.; Hattendorf, B.; Wennemers, H. Peptide-Coated Platinum Nanoparticles with Selective Toxicity against Liver Cancer Cells. Angew. Chem. Int. Ed. 2019, 58, 4901-4905. [CrossRef]

96. Medhat, A.; Mansour, S.; El-Sonbaty, S.; Kandil, E.; Mahmoud, M. Evaluation of the antitumor activity of platinum nanoparticles in the treatment of hepatocellular carcinoma induced in rats. Tumor Biol. 2017, 39, 1010428317717259. [CrossRef] [PubMed]

97. Feng, S.; Zhou, J.; Li, Z.; Appelman, H.D.; Zhao, L.; Zhu, J.; Wang, T.D. Sorafenib encapsulated in nanocarrier functionalized with glypican-3 specific peptide for targeted therapy of hepatocellular carcinoma. Colloids Surf. B Biointerfaces 2019, 184, 110498. [CrossRef]

98. Gao, X.; He, Z.; Ni, W.; Jian, X.; Hu, C.; Zhao, Y.; Yan, Y.; Wei, X. Layer-by-Layer Assembly of Functional Nanoparticles for Hepatocellular Carcinoma Therapy. Adv. Funct. Mater. 2019, 29, 1904246. [CrossRef]

99. Song, X.; You, J.; Shao, H.; Yan, C. Effects of surface modification of $\mathrm{As}_{2} \mathrm{O}_{3}$-loaded PLGA nanoparticles on its anti-liver cancer ability: An in vitro and in vivo study. Colloids Surf. B Biointerfaces 2018, 169, 289-297. [CrossRef]

100. Song, X.; Wang, J.; Xu, Y.; Shao, H.; Gu, J. Surface-modified PLGA nanoparticles with PEG/LA-chitosan for targeted delivery of arsenic trioxide for liver cancer treatment: Inhibition effects enhanced and side effects reduced. Colloids Surf. B Biointerfaces 2019, 180, 110-117. [CrossRef] [PubMed]

101. Chen, Y.; Liu, Y.-C.; Sung, Y.-C.; Ramjiawan, R.R.; Lin, T.-T.; Chang, C.-C.; Jeng, K.-S.; Chang, C.-F.; Liu, C.-H.; Gao, D.-Y. Overcoming sorafenib evasion in hepatocellular carcinoma using CXCR4-targeted nanoparticles to co-deliver MEK-inhibitors. Sci. Rep. 2017, 7, 44123. [CrossRef] [PubMed]

102. Wu, B.; Liang, Y.; Tan, Y.; Xie, C.; Shen, J.; Zhang, M.; Liu, X.; Yang, L.; Zhang, F.; Liu, L. Genistein-loaded nanoparticles of star-shaped diblock copolymer mannitol-core PLGA-TPGS for the treatment of liver cancer. Mater. Sci. Eng. C 2016, 59, 792-800. [CrossRef] [PubMed]

103. Liu, Y.; Zong, Y.; Yang, Z.; Luo, M.; Li, G.; Yingsa, W.; Cao, Y.; Xiao, M.; Kong, T.; He, J. Dual-targeted controlled delivery based on folic acid modified pectin-based nanoparticles for combination therapy of liver cancer. Am. Chem. Soc. Sustain. Chem. Eng. 2019, 7, 3614-3623. [CrossRef]

104. Huang, L.; Chaurasiya, B.; Wu, D.; Wang, H.; Du, Y.; Tu, J.; Webster, T.J.; Sun, C. Versatile redox-sensitive pullulan nanoparticles for enhanced liver targeting and efficient cancer therapy. Nanomed. Nanotechnol. Biol. Med. 2018, 14, 1005-1017. [CrossRef] [PubMed]

105. Xia, Y.; Zhong, J.; Zhao, M.; Tang, Y.; Han, N.; Hua, L.; Xu, T.; Wang, C.; Zhu, B. Galactose-modified selenium nanoparticles for targeted delivery of doxorubicin to hepatocellular carcinoma. Drug Deliv. 2019, 26, 1-11. [CrossRef] [PubMed] 
106. Xia, Y.; Zhao, M.; Chen, Y.; Hua, L.; Xu, T.; Wang, C.; Li, Y.; Zhu, B. Folate-targeted selenium nanoparticles deliver therapeutic siRNA to improve hepatocellular carcinoma therapy. RSC Adv. 2018, 8, 25932-25940. [CrossRef]

107. Fang, X.; Wu, X.; Zhou, B.; Chen, X.; Chen, T.; Yang, F. Targeting selenium nanoparticles combined with baicalin to treat HBV-infected liver cancer. RSC Adv. 2017, 7, 8178-8185. [CrossRef]

108. Al-Nadaf, A.H.; Dahabiyeh, L.A.; Bardaweel, S.; Mahmoud, N.N.; Jawarneh, S. Functionalized mesoporous silica nanoparticles by lactose and hydrophilic polymer as a hepatocellular carcinoma drug delivery system. J. Drug Deliv. Sci. Technol. 2020, 56, 101504. [CrossRef]

109. Yang, H.; Liu, H.-s.; Hou, W.; Gao, J.-x.; Duan, Y.; Wei, D.; Gong, X.-q.; Wang, H.-j.; Wu, X.-1.; Chang, J. An NIR-responsive mesoporous silica nanosystem for synergetic photothermal-immunoenhancement therapy of hepatocellular carcinoma. J. Mater. Chem. B 2020, 8, 251-259. [CrossRef]

110. Niu, Y.; Tang, E.; Zhang, Q. Cytotoxic effect of silica nanoparticles against hepatocellular carcinoma cells through necroptosis induction. Toxicol. Res. 2019, 8, 1042-1049. [CrossRef]

111. Ma, W.; Zhu, D.; Li, J.; Chen, X.; Xie, W.; Jiang, X.; Wu, L.; Wang, G.; Xiao, Y.; Liu, Z. Coating biomimetic nanoparticles with chimeric antigen receptor $\mathrm{T}$ cell-membrane provides high specificity for hepatocellular carcinoma photothermal therapy treatment. Theranostics 2020, 10, 1281. [CrossRef]

112. Wang, Z.; Chang, Z.; Lu, M.; Shao, D.; Yue, J.; Yang, D.; Zheng, X.; Li, M.; He, K.; Zhang, M. Shape-controlled magnetic mesoporous silica nanoparticles for magnetically-mediated suicide gene therapy of hepatocellular carcinoma. Biomaterials 2018, 154, 147-157. [CrossRef]

113. Wang, Z.; Wu, P.; He, Z.; He, H.; Rong, W.; Li, J.; Zhou, D.; Huang, Y. Mesoporous silica nanoparticles with lactose-mediated targeting effect to deliver platinum (IV) prodrug for liver cancer therapy. J. Mater. Chem. B 2017, 5, 7591-7597. [CrossRef]

114. Xue, H.; Yu, Z.; Liu, Y.; Yuan, W.; Yang, T.; You, J.; He, X.; Lee, R.J.; Li, L.; Xu, C. Delivery of miR-375 and doxorubicin hydrochloride by lipid-coated hollow mesoporous silica nanoparticles to overcome multiple drug resistance in hepatocellular carcinoma. Int. J. Nanomed. 2017, 12, 5271. [CrossRef] [PubMed]

115. Lv, Y.; Li, J.; Chen, H.; Bai, Y.; Zhang, L. Glycyrrhetinic acid-functionalized mesoporous silica nanoparticles as hepatocellular carcinoma-targeted drug carrier. Int. J. Nanomed. 2017, 12, 4361. [CrossRef] [PubMed]

116. Wang, J.-k.; Zhou, Y.-y.; Guo, S.-j.; Wang, Y.-y.; Nie, C.-j.; Wang, H.-1.; Wang, J.-l.; Zhao, Y.; Li, X.-y.; Chen, X.-j. Cetuximab conjugated and doxorubicin loaded silica nanoparticles for tumor-targeting and tumor microenvironment responsive binary drug delivery of liver cancer therapy. Mater. Sci. Eng. C 2017, 76, 944-950. [CrossRef] [PubMed]

117. Li, T.; Chen, X.; Liu, Y.; Fan, L.; Lin, L.; Xu, Y.; Chen, S.; Shao, J. pH-Sensitive mesoporous silica nanoparticles anticancer prodrugs for sustained release of ursolic acid and the enhanced anti-cancer efficacy for hepatocellular carcinoma cancer. Eur. J. Pharm. Sci. 2017, 96, 456-463. [CrossRef]

118. Liao, Y.-T.; Liu, C.-H.; Yu, J.; Wu, K.C. Liver cancer cells: Targeting and prolonged-release drug carriers consisting of mesoporous silica nanoparticles and alginate microspheres. Int. J. Nanomed. 2014, 9, 2767.

119. Karimzadeh, K.; Bakhshi, N.; Ramzanpoor, M. Biogenic silver nanoparticles using Oxalis corniculata characterization and their clinical implications. J. Drug Deliv. Sci. Technol. 2019, 54, 101263. [CrossRef]

120. Ahmadian, E.; Dizaj, S.M.; Rahimpour, E.; Hasanzadeh, A.; Eftekhari, A.; Halajzadeh, J.; Ahmadian, H. Effect of silver nanoparticles in the induction of apoptosis on human hepatocellular carcinoma (HepG2) cell line. Mater. Sci. Eng. C 2018, 93, 465-471. [CrossRef]

121. Saratale, R.G.; Shin, H.S.; Kumar, G.; Benelli, G.; Kim, D.-S.; Saratale, G.D. Exploiting antidiabetic activity of silver nanoparticles synthesized using Punica granatum leaves and anticancer potential against human liver cancer cells (HepG2). Artif. Cells Nanomed. Biotechnol. 2018, 46, 211-222. [CrossRef] [PubMed]

122. Jaganathan, A.; Murugan, K.; Panneerselvam, C.; Madhiyazhagan, P.; Dinesh, D.; Vadivalagan, C.; Chandramohan, B.; Suresh, U.; Rajaganesh, R.; Subramaniam, J. Earthworm-mediated synthesis of silver nanoparticles: A potent tool against hepatocellular carcinoma, Plasmodium falciparum parasites and malaria mosquitoes. Parasitol. Int. 2016, 65, 276-284. [CrossRef]

123. Wang, Y.; Zhang, Y.; Guo, Y.; Lu, J.; Veeraraghavan, V.P.; Mohan, S.K.; Wang, C.; Yu, X. Synthesis of Zinc oxide nanoparticles from Marsdenia tenacissima inhibits the cell proliferation and induces apoptosis in laryngeal cancer cells (Hep-2). J. Photochem. Photobiol. B Biol. 2019, 201, 111624. [CrossRef] [PubMed]

124. Xu, X.; Liu, C.; Wang, Y.; Koivisto, O.; Zhou, J.; Shu, Y.; Zhang, H. Nanotechnology-based delivery of CRISPR/Cas9 for cancer treatment. Adv. Drug Deliv. Rev. 2021, 176, 113891. [CrossRef]

125. Skoulidis, F.; Heymach, J.V. Co-occurring genomic alterations in non-small-cell lung cancer biology and therapy. Nat. Rev. Cancer 2019, 19, 495-509. [CrossRef] [PubMed]

126. Martínez-Jiménez, F.; Muiños, F.; Sentís, I.; Deu-Pons, J.; Reyes-Salazar, I.; Arnedo-Pac, C.; Mularoni, L.; Pich, O.; Bonet, J.; Kranas, H. A compendium of mutational cancer driver genes. Nat. Rev. Cancer 2020, 20, 555-572. [CrossRef]

127. Azangou-Khyavy, M.; Ghasemi, M.; Khanali, J.; Boroomand-Saboor, M.; Jamalkhah, M.; Soleimani, M.; Kiani, J. CRISPR/Cas: From tumor gene editing to T cell-based immunotherapy of cancer. Front. Immunol. 2020, 11, 2062. [CrossRef]

128. Montaño-Samaniego, M.; Bravo-Estupiñan, D.M.; Méndez-Guerrero, O.; Alarcón-Hernández, E.; Ibáñez-Hernández, M. Strategies for Targeting Gene Therapy in Cancer Cells With Tumor-Specific Promoters. Front. Oncol. 2020, 10, 2671. [CrossRef] [PubMed]

129. Reghupaty, S.C.; Sarkar, D. Current status of gene therapy in hepatocellular carcinoma. Cancers 2019, 11, 1265. [CrossRef] [PubMed] 
130. Tabernero, J.; Shapiro, G.I.; LoRusso, P.M.; Cervantes, A.; Schwartz, G.K.; Weiss, G.J.; Paz-Ares, L.; Cho, D.C.; Infante, J.R.; Alsina, M. First-in-humans trial of an RNA interference therapeutic targeting VEGF and KSP in cancer patients with liver involvement. Cancer Discov. 2013, 3, 406-417. [CrossRef]

131. Zhong, J.; Huang, H.-L.; Li, J.; Qian, F.-C.; Li, L.-Q.; Niu, P.-P.; Dai, L.-C. Development of hybrid-type modified chitosan derivative nanoparticles for the intracellular delivery of midkine-siRNA in hepatocellular carcinoma cells. Hepatobiliary Pancreat. Dis. Int. 2015, 14, 82-89. [CrossRef]

132. Wang, D.; Chang, R.; Wang, G.; Hu, B.; Qiang, Y.; Chen, Z. Polo-like kinase 1-targeting Chitosan Nanoparticles suppress the progression of hepatocellular carcinoma. Anti-Cancer Agents Med. Chem. (Former. Curr. Med. Chem. Anti-Cancer Agents) 2017, 17, 948-954. [CrossRef] [PubMed]

133. Bogorad, R.L.; Yin, H.; Zeigerer, A.; Nonaka, H.; Ruda, V.M.; Zerial, M.; Anderson, D.G.; Koteliansky, V. Nanoparticle-formulated siRNA targeting integrins inhibits hepatocellular carcinoma progression in mice. Nat. Commun. 2014, 5, 3869. [CrossRef] [PubMed]

134. Hsu, S.-h.; Yu, B.; Wang, X.; Lu, Y.; Schmidt, C.R.; Lee, R.J.; Lee, L.J.; Jacob, S.T.; Ghoshal, K. Cationic lipid nanoparticles for therapeutic delivery of siRNA and miRNA to murine liver tumor. Nanomed. Nanotechnol. Biol. Med. 2013, 9, 1169-1180. [CrossRef] [PubMed]

135. Wu, Z.; Xu, X.-L.; Zhang, J.-Z.; Mao, X.-H.; Xie, M.-W.; Cheng, Z.-L.; Lu, L.-J.; Duan, X.-H.; Zhang, L.-M.; Shen, J. Magnetic cationic amylose nanoparticles used to deliver survivin-small interfering RNA for gene therapy of hepatocellular carcinoma in vitro. Nanomaterials 2017, 7, 110. [CrossRef] [PubMed]

136. Wang, K.; Kievit, F.M.; Sham, J.G.; Jeon, M.; Stephen, Z.R.; Bakthavatsalam, A.; Park, J.O.; Zhang, M. Iron-oxide-based nanovector for tumor targeted siRNA delivery in an orthotopic hepatocellular carcinoma xenograft mouse model. Small 2016, 12, $477-487$. [CrossRef] [PubMed]

137. Rajasekaran, D.; Srivastava, J.; Ebeid, K.; Gredler, R.; Akiel, M.; Jariwala, N.; Robertson, C.L.; Shen, X.-N.; Siddiq, A.; Fisher, P.B. Combination of nanoparticle-delivered siRNA for astrocyte elevated gene-1 (AEG-1) and all-trans retinoic acid (ATRA): An effective therapeutic strategy for hepatocellular carcinoma (HCC). Bioconjugate Chem. 2015, 26, 1651-1661. [CrossRef] [PubMed]

138. Zheng, G.; Zhao, R.; Xu, A.; Shen, Z.; Chen, X.; Shao, J. Co-delivery of sorafenib and siVEGF based on mesoporous silica nanoparticles for ASGPR mediated targeted HCC therapy. Eur. J. Pharm. Sci. 2018, 111, 492-502. [CrossRef]

139. Younis, M.A.; Khalil, I.A.; Abd Elwakil, M.M.; Harashima, H. A multifunctional lipid-based nanodevice for the highly specific codelivery of sorafenib and midkine siRNA to hepatic cancer cells. Mol. Pharm. 2019, 16, 4031-4044. [CrossRef]

140. Yang, T.; Chen, Y.; Zhao, P.; Xue, H.; You, J.; Li, B.; Liu, Y.; He, C.; Zhang, X.; Fan, L. Enhancing the therapeutic effect via elimination of hepatocellular carcinoma stem cells using Bmi1 siRNA delivered by cationic cisplatin nanocapsules. Nanomed. Nanotechnol. Biol. Med. 2018, 14, 2009-2021. [CrossRef]

141. Yang, J.D.; Nakamura, I.; Roberts, L.R. The tumor microenvironment in hepatocellular carcinoma: Current status and therapeutic targets. In Seminars in Cancer Biology; Elsevier: Amsterdam, The Netherlands, 2011; pp. 35-43.

142. Friedman, S.L.; Roll, F.J.; Boyles, J.; Bissell, D.M. Hepatic lipocytes: The principal collagen-producing cells of normal rat liver. Proc. Natl. Acad. Sci. USA 1985, 82, 8681-8685. [CrossRef]

143. Pietras, K.; Östman, A. Hallmarks of cancer: Interactions with the tumor stroma. Exp. Cell Res. 2010, 316, 1324-1331. [CrossRef] [PubMed]

144. Benetti, A.; Berenzi, A.; Gambarotti, M.; Garrafa, E.; Gelati, M.; Dessy, E.; Portolani, N.; Piardi, T.; Giulini, S.M.; Caruso, A. Transforming growth factor- $\beta 1$ and CD105 promote the migration of hepatocellular carcinoma-derived endothelium. Cancer Res. 2008, 68, 8626-8634. [CrossRef]

145. Kessenbrock, K.; Plaks, V.; Werb, Z. Matrix metalloproteinases: Regulators of the tumor microenvironment. Cell 2010, $141,52-67$. [CrossRef] [PubMed]

146. Kalyane, D.; Raval, N.; Maheshwari, R.; Tambe, V.; Kalia, K.; Tekade, R.K. Employment of enhanced permeability and retention effect (EPR): Nanoparticle-based precision tools for targeting of therapeutic and diagnostic agent in cancer. Mater. Sci. Eng. C 2019, 98, 1252-1276. [CrossRef] [PubMed]

147. Balkwill, F.R.; Capasso, M.; Hagemann, T. The tumor microenvironment at a glance. J. Cell Sci. 2012, 125, 5591-5596. [CrossRef]

148. Whiteside, T. The tumor microenvironment and its role in promoting tumor growth. Oncogene 2008, 27, 5904-5912. [CrossRef] [PubMed]

149. Ruoslahti, E. Antiangiogenics meet nanotechnology. Cancer Cell 2002, 2, 97-98. [CrossRef]

150. Siemann, D.W. The unique characteristics of tumor vasculature and preclinical evidence for its selective disruption by tumorvascular disrupting agents. Cancer Treat. Rev. 2011, 37, 63-74. [CrossRef]

151. Byrne, J.D.; Betancourt, T.; Brannon-Peppas, L. Active targeting schemes for nanoparticle systems in cancer therapeutics. Adv Drug Deliv. Rev. 2008, 60, 1615-1626. [CrossRef] [PubMed]

152. Maeda, H.; Wu, J.; Sawa, T.; Matsumura, Y.; Hori, K. Tumor vascular permeability and the EPR effect in macromolecular therapeutics: A review. J. Control. Release 2000, 65, 271-284. [CrossRef]

153. Bosch, J. Vascular deterioration in cirrhosis: The big picture. J. Clin. Gastroenterol. 2007, 41, S247-S253. [CrossRef]

154. Trédan, O.; Galmarini, C.M.; Patel, K.; Tannock, I.F. Drug resistance and the solid tumor microenvironment. J. Natl. Cancer Inst. 2007, 99, 1441-1454. [CrossRef] [PubMed] 
155. Nichols, J.W.; Bae, Y.H. Odyssey of a cancer nanoparticle: From injection site to site of action. Nano Today 2012, 7, 606-618. [CrossRef] [PubMed]

156. Gallagher, F.A.; Kettunen, M.I.; Day, S.E.; Hu, D.-E.; Ardenkjaer-Larsen, J.H.; Jensen, P.R.; Karlsson, M.; Golman, K.; Lerche, M.H.; Brindle, K.M. Magnetic resonance imaging of $\mathrm{pH}$ in vivo using hyperpolarized 13 C-labelled bicarbonate. Nature 2008, 453 , 940-943. [CrossRef]

157. Urano, Y.; Asanuma, D.; Hama, Y.; Koyama, Y.; Barrett, T.; Kamiya, M.; Nagano, T.; Watanabe, T.; Hasegawa, A.; Choyke, P.L. Selective molecular imaging of viable cancer cells with pH-activatable fluorescence probes. Nat. Med. 2009, 15, 104-109. [CrossRef] [PubMed]

158. Van Hong Nguyen, B.-J.L. Protein corona: A new approach for nanomedicine design. Int. J. Nanomed. 2017, 12, 3137. [CrossRef] [PubMed]

159. Cai, R.; Chen, C. The crown and the scepter: Roles of the protein corona in nanomedicine. Adv. Mater. 2019, 31, 1805740. [CrossRef] [PubMed]

160. Cedervall, T.; Lynch, I.; Lindman, S.; Berggård, T.; Thulin, E.; Nilsson, H.; Dawson, K.A.; Linse, S. Understanding the nanoparticleprotein corona using methods to quantify exchange rates and affinities of proteins for nanoparticles. Proc. Natl. Acad. Sci. USA 2007, 104, 2050-2055. [CrossRef]

161. Ke, P.C.; Lin, S.; Parak, W.J.; Davis, T.P.; Caruso, F. A decade of the protein corona. Am. Chem. Soc. Nano 2017, 11, 11773-11776. [CrossRef] [PubMed]

162. Rampado, R.; Crotti, S.; Caliceti, P.; Pucciarelli, S.; Agostini, M. Recent advances in understanding the protein corona of nanoparticles and in the formulation of "Stealthy" Nanomaterials. Front. Bioeng. Biotechnol. 2020, 8, 166. [CrossRef]

163. Xu, F.; Reiser, M.; Yu, X.; Gummuluru, S.; Wetzler, L.; Reinhard, B.M. Lipid-mediated targeting with membrane-wrapped nanoparticles in the presence of corona formation. Am. Chem. Soc. Nano 2016, 10, 1189-1200. [CrossRef] [PubMed]

164. Magro, M.; Baratella, D.; Bonaiuto, E.; de Almeida, R.J.; Chemello, G.; Pasquaroli, S.; Mancini, L.; Olivotto, I.; Zoppellaro, G.; Ugolotti, J. Stealth iron oxide nanoparticles for organotropic drug targeting. Biomacromolecules 2019, 20, 1375-1384. [CrossRef]

165. García-Álvarez, R.; Hadjidemetriou, M.; Sánchez-Iglesias, A.; Liz-Marzán, L.M.; Kostarelos, K. In vivo formation of protein corona on gold nanoparticles. The effect of their size and shape. Nanoscale 2018, 10, 1256-1264. [CrossRef] [PubMed]

166. Saha, K.; Rahimi, M.; Yazdani, M.; Kim, S.T.; Moyano, D.F.; Hou, S.; Das, R.; Mout, R.; Rezaee, F.; Mahmoudi, M. Regulation of macrophage recognition through the interplay of nanoparticle surface functionality and protein corona. Am. Chem. Soc. Nano 2016, 10, 4421-4430. [CrossRef]

167. Almalik, A.; Benabdelkamel, H.; Masood, A.; Alanazi, I.O.; Alradwan, I.; Majrashi, M.A.; Alfadda, A.A.; Alghamdi, W.M.; Alrabiah, H.; Tirelli, N. Hyaluronic acid coated chitosan nanoparticles reduced the immunogenicity of the formed protein corona. Sci. Rep. 2017, 7, 10542. [CrossRef] [PubMed]

168. Partikel, K.; Korte, R.; Mulac, D.; Humpf, H.-U.; Langer, K. Serum type and concentration both affect the protein-corona composition of PLGA nanoparticles. Beilstein J. Nanotechnol. 2019, 10, 1002-1015. [CrossRef] [PubMed]

169. Monopoli, M.P.; Åberg, C.; Salvati, A.; Dawson, K.A. Biomolecular coronas provide the biological identity of nanosized materials. Nat. Nanotechnol. 2012, 7, 779-786. [CrossRef]

170. Vroman, L.; Lukosevicius, A. Ellipsometer recordings of changes in optical thickness of adsorbed films associated with surface activation of blood clotting. Nature 1964, 204, 701-703. [CrossRef] [PubMed]

171. Vroman, L.; Adams, A.; Fischer, G.; Munoz, P. Interaction of high molecular weight kininogen, factor XII, and fibrinogen in plasma at interfaces. Blood 1980, 55, 156-159. [CrossRef] [PubMed]

172. Hadjidemetriou, M.; Kostarelos, K. Evolution of the nanoparticle corona. Nat. Nanotechnol. 2017, 12, 288-290. [CrossRef] [PubMed]

173. Wilhelm, S.; Tavares, A.J.; Dai, Q.; Ohta, S.; Audet, J.; Dvorak, H.F.; Chan, W.C. Analysis of nanoparticle delivery to tumours. Nat. Rev. Mater. 2016, 1, 16014. [CrossRef]

174. Maiolo, D.; Del Pino, P.; Metrangolo, P.; Parak, W.J.; Baldelli Bombelli, F. Nanomedicine delivery: Does protein corona route to the target or off road? Nanomedicine 2015, 10, 3231-3247. [CrossRef] [PubMed]

175. Oh, J.Y.; Kim, H.S.; Palanikumar, L.; Go, E.M.; Jana, B.; Park, S.A.; Kim, H.Y.; Kim, K.; Seo, J.K.; Kwak, S.K. Cloaking nanoparticles with protein corona shield for targeted drug delivery. Nat. Commun. 2018, 9, 4548. [CrossRef]

176. Mizuhara, T.; Saha, K.; Moyano, D.F.; Kim, C.S.; Yan, B.; Kim, Y.K.; Rotello, V.M. Acylsulfonamide-functionalized zwitterionic gold nanoparticles for enhanced cellular uptake at tumor pH. Angew. Chem. 2015, 127, 6667-6670. [CrossRef]

177. Kang, B.; Okwieka, P.; Schöttler, S.; Winzen, S.; Langhanki, J.; Mohr, K.; Opatz, T.; Mailänder, V.; Landfester, K.; Wurm, F.R. Carbohydrate-based nanocarriers exhibiting specific cell targeting with minimum influence from the protein corona. Angew. Chem. Int. Ed. 2015, 54, 7436-7440. [CrossRef] [PubMed]

178. Dai, Q.; Walkey, C.; Chan, W.C. Polyethylene glycol backfilling mitigates the negative impact of the protein corona on nanoparticle cell targeting. Angew. Chem. Int. Ed. 2014, 53, 5093-5096. [CrossRef] [PubMed]

179. Wan, S.; Kelly, P.M.; Mahon, E.; Stockmann, H.; Rudd, P.M.; Caruso, F.; Dawson, K.A.; Yan, Y.; Monopoli, M.P. The "sweet" side of the protein corona: Effects of glycosylation on nanoparticle-cell interactions. Am. Chem. Soc. Nano 2015, 9, 2157-2166. [CrossRef] [PubMed]

180. Corbo, C.; Molinaro, R.; Tabatabaei, M.; Farokhzad, O.C.; Mahmoudi, M. Personalized protein corona on nanoparticles and its clinical implications. Biomater. Sci. 2017, 5, 378-387. [CrossRef] [PubMed] 
181. Ren, J.; Cai, R.; Wang, J.; Daniyal, M.; Baimanov, D.; Liu, Y.; Yin, D.; Liu, Y.; Miao, Q.; Zhao, Y. Precision nanomedicine development based on specific opsonization of human cancer patient-personalized protein coronas. Nano Lett. 2019, 19, 4692-4701. [CrossRef]

182. Barui, A.K.; Oh, J.Y.; Jana, B.; Kim, C.; Ryu, J.H. Cancer-targeted nanomedicine: Overcoming the barrier of the protein corona. Adv. Ther. 2020, 3, 1900124. [CrossRef]

183. Parmar, K.; Patel, J.K. Surface Modification of Nanoparticles to Oppose Uptake by the Mononuclear Phagocyte System. In Surface Modification of Nanoparticles for Targeted Drug Delivery; Springer: Berlin/Heidelberg, Germany, 2019; pp. 221-236.

184. Allen, T. The use of glycolipids and hydrophilic polymers in avoiding rapid uptake of liposomes by the mononuclear phagocyte system. Adv. Drug Deliv. Rev. 1994, 13, 285-309. [CrossRef]

185. Crispe, I.N. Liver antigen-presenting cells. J. Hepatol. 2011, 54, 357-365. [CrossRef] [PubMed]

186. Strauss, O.; Dunbar, P.R.; Bartlett, A.; Phillips, A. The immunophenotype of antigen presenting cells of the mononuclear phagocyte system in normal human liver-A systematic review. J. Hepatol. 2015, 62, 458-468. [CrossRef]

187. Jenne, C.N.; Kubes, P. Immune surveillance by the liver. Nat. Immunol. 2013, 14, 996-1006. [CrossRef]

188. Geissmann, F.; Gordon, S.; Hume, D.A.; Mowat, A.M.; Randolph, G.J. Unravelling mononuclear phagocyte heterogeneity. Nat. Rev. Immunol. 2010, 10, 453-460. [CrossRef]

189. Wake, K. Karl Wilhelm Kupffer and his contributions to modern hepatology. Comp. Hepatol. 2004, 3, S2. [CrossRef]

190. Lu, J.; Wang, J.; Ling, D. Surface engineering of nanoparticles for targeted delivery to hepatocellular carcinoma. Small 2018, 14, 1702037. [CrossRef]

191. Zhang, Y.-N.; Poon, W.; Tavares, A.J.; McGilvray, I.D.; Chan, W.C. Nanoparticle-liver interactions: Cellular uptake and hepatobiliary elimination. J. Control. Release 2016, 240, 332-348. [CrossRef] [PubMed]

192. Tavares, A.J.; Poon, W.; Zhang, Y.-N.; Dai, Q.; Besla, R.; Ding, D.; Ouyang, B.; Li, A.; Chen, J.; Zheng, G. Effect of removing Kupffer cells on nanoparticle tumor delivery. Proc. Natl. Acad. Sci. USA 2017, 114, E10871-E10880. [CrossRef] [PubMed]

193. Sadauskas, E.; Wallin, H.; Stoltenberg, M.; Vogel, U.; Doering, P.; Larsen, A.; Danscher, G. Kupffer cells are central in the removal of nanoparticles from the organism. Part. Fibre Toxicol. 2007, 4, 10. [CrossRef]

194. Owens, D.E., III; Peppas, N.A. Opsonization, biodistribution, and pharmacokinetics of polymeric nanoparticles. Int. J. Pharm. 2006, 307, 93-102. [CrossRef] [PubMed]

195. Karakoti, A.S.; Das, S.; Thevuthasan, S.; Seal, S. PEGylated inorganic nanoparticles. Angew. Chem. Int. Ed. 2011, 50, 1980-1994. [CrossRef] [PubMed]

196. García, K.P.; Zarschler, K.; Barbaro, L.; Barreto, J.A.; O’Malley, W.; Spiccia, L.; Stephan, H.; Graham, B. Zwitterionic-coated "stealth" nanoparticles for biomedical applications: Recent advances in countering biomolecular corona formation and uptake by the mononuclear phagocyte system. Small 2014, 10, 2516-2529. [CrossRef] [PubMed]

197. Shi, B.; Abrams, M.; Sepp-Lorenzino, L. Expression of asialoglycoprotein receptor 1 in human hepatocellular carcinoma. J. Histochem. Cytochem. 2013, 61, 901-909. [CrossRef]

198. Varshosaz, J.; Hassanzadeh, F.; Sadeghi, H.; Khadem, M. Galactosylated nanostructured lipid carriers for delivery of 5-FU to hepatocellular carcinoma. J. Liposome Res. 2012, 22, 224-236. [CrossRef] [PubMed]

199. Terada, T.; Iwai, M.; Kawakami, S.; Yamashita, F.; Hashida, M. Novel PEG-matrix metalloproteinase-2 cleavable peptide-lipid containing galactosylated liposomes for hepatocellular carcinoma-selective targeting. J. Control. Release 2006, 111, 333-342. [CrossRef] [PubMed]

200. Mok, T.S.; Leung, T.W.; Brown, G.; Moyses, C.; Chan, A.T.; Yeo, W.; Wong, H.; Chak, K.; Johnson, P. A phase I safety and pharmacokinetic study of OGT 719 in patients with liver cancer. Acta Oncol. 2004, 43, 245-251. [CrossRef]

201. D'souza, A.A.; Devarajan, P.V. Asialoglycoprotein receptor mediated hepatocyte targeting-Strategies and applications. J. Control. Release 2015, 203, 126-139. [CrossRef] [PubMed]

202. Wall, D.A.; Hubbard, A.L. Galactose-specific recognition system of mammalian liver: Receptor distribution on the hepatocyte cell surface. J. Cell Biol. 1981, 90, 687-696. [CrossRef]

203. Matsuura, S.; Nakada, H.; Sawamura, T.; Tashiro, Y. Distribution of an asialoglycoprotein receptor on rat hepatocyte cell surface. J. Cell Biol. 1982, 95, 864-875. [CrossRef]

204. Spiess, M. The asialoglycoprotein receptor: A model for endocytic transport receptors. Biochemistry 1990, 29, 10009-10018. [CrossRef] [PubMed]

205. Ishibashi, S.; Hammer, R.E.; Herz, J. Asialoglycoprotein receptor deficiency in mice lacking the minor receptor subunit. J. Biol. Chem. 1994, 269, 27803-27806. [CrossRef]

206. Rozema, D.B.; Lewis, D.L.; Wakefield, D.H.; Wong, S.C.; Klein, J.J.; Roesch, P.L.; Bertin, S.L.; Reppen, T.W.; Chu, Q.; Blokhin, A.V. Dynamic PolyConjugates for targeted in vivo delivery of siRNA to hepatocytes. Proc. Natl. Acad. Sci. USA 2007, 104, 12982-12987. [CrossRef] [PubMed]

207. Trere, D.; Fiume, L.; De Giorgi, L.B.; Di Stefano, G.; Migaldi, M.; Derenzini, M. The asialoglycoprotein receptor in human hepatocellular carcinomas: Its expression on proliferating cells. Br. J. Cancer 1999, 81, 404-408. [CrossRef]

208. Julyan, P.J.; Seymour, L.W.; Ferry, D.R.; Daryani, S.; Boivin, C.M.; Doran, J.; David, M.; Anderson, D.; Christodoulou, C.; Young, A.M. Preliminary clinical study of the distribution of HPMA copolymers bearing doxorubicin and galactosamine. J. Control. Release 1999, 57, 281-290. [CrossRef] 
209. Seymour, L.W.; Ferry, D.R.; Anderson, D.; Hesslewood, S.; Julyan, P.J.; Poyner, R.; Doran, J.; Young, A.M.; Burtles, S.; Kerr, D.J. Hepatic drug targeting: Phase I evaluation of polymer-bound doxorubicin. J. Clin. Oncol. 2002, 20, 1668-1676. [CrossRef] [PubMed]

210. Ise, H.; Nikaido, T.; Negishi, N.; Sugihara, N.; Suzuki, F.; Akaike, T.; Ikeda, U. Effective hepatocyte transplantation using rat hepatocytes with low asialoglycoprotein receptor expression. Am. J. Pathol. 2004, 165, 501-510. [CrossRef]

211. Lu, C.; Xing, M.M.; Zhong, W. Shell cross-linked and hepatocyte-targeting nanoparticles containing doxorubicin via acid-cleavable linkage. Nanomed. Nanotechnol. Biol. Med. 2011, 7, 80-87. [CrossRef] [PubMed]

212. Shinoda, T.; Maeda, A.; Kagatani, S.; Konno, Y.; Sonobe, T.; Fukui, M.; Hashimoto, H.; Hara, K.; Fujita, K. Specific interaction between galactose branched-cyclodextrins and hepatocytes in vitro. Int. J. Pharm. 1998, 167, 147-154. [CrossRef]

213. Zou, Y.; Song, Y.; Yang, W.; Meng, F.; Liu, H.; Zhong, Z. Galactose-installed photo-crosslinked pH-sensitive degradable micelles for active targeting chemotherapy of hepatocellular carcinoma in mice. J. Control. Release 2014, 193, 154-161. [CrossRef] [PubMed]

214. Shen, Z.; Wei, W.; Tanaka, H.; Kohama, K.; Ma, G.; Dobashi, T.; Maki, Y.; Wang, H.; Bi, J.; Dai, S. A galactosamine-mediated drug delivery carrier for targeted liver cancer therapy. Pharmacol. Res. 2011, 64, 410-419. [CrossRef] [PubMed]

215. Wei, M.; Xu, Y.; Zou, Q.; Tu, L.; Tang, C.; Xu, T.; Deng, L.; Wu, C. Hepatocellular carcinoma targeting effect of PEGylated liposomes modified with lactoferrin. Eur. J. Pharm. Sci. 2012, 46, 131-141. [CrossRef] [PubMed]

216. Filmus, J.; Capurro, M. Glypican-3: A marker and a therapeutic target in hepatocellular carcinoma. FEBS J. 2013, 280, 2471-2476. [CrossRef] [PubMed]

217. Feng, M.; Ho, M. Glypican-3 antibodies: A new therapeutic target for liver cancer. FEBS Lett. 2014, 588, 377-382. [CrossRef] [PubMed]

218. Filmus, J.; Selleck, S.B. Glypicans: Proteoglycans with a surprise. J. Clin. Investig. 2001, 108, 497-501. [CrossRef] [PubMed]

219. Ho, M.; Kim, H. Glypican-3: A new target for cancer immunotherapy. Eur. J. Cancer 2011, 47, 333-338. [CrossRef] [PubMed]

220. Ishiguro, T.; Sugimoto, M.; Kinoshita, Y.; Miyazaki, Y.; Nakano, K.; Tsunoda, H.; Sugo, I.; Ohizumi, I.; Aburatani, H.; Hamakubo, T. Anti-glypican 3 antibody as a potential antitumor agent for human liver cancer. Cancer Res. 2008, 68, 9832-9838. [CrossRef]

221. Nakano, K.; Ishiguro, T.; Konishi, H.; Tanaka, M.; Sugimoto, M.; Sugo, I.; Igawa, T.; Tsunoda, H.; Kinoshitam, Y.; Habu, K. Generation of a humanized anti-glypican 3 antibody by CDR grafting and stability optimization. Anti-Cancer Drugs 2010, 21, 907-916. [CrossRef] [PubMed]

222. Nakano, K.; Orita, T.; Nezu, J.; Yoshino, T.; Ohizumi, I.; Sugimoto, M.; Furugaki, K.; Kinoshita, Y.; Ishiguro, T.; Hamakubo, T. Anti-glypican 3 antibodies cause ADCC against human hepatocellular carcinoma cells. Biochem. Biophys. Res. Commun. 2009, 378, 279-284. [CrossRef]

223. Zhu, A.X.; Gold, P.J.; El-Khoueiry, A.B.; Abrams, T.A.; Morikawa, H.; Ohishi, N.; Ohtomo, T.; Philip, P.A. First-in-man phase I study of GC33, a novel recombinant humanized antibody against glypican-3, in patients with advanced hepatocellular carcinoma. Clin. Cancer Res. 2013, 19, 920-928. [CrossRef]

224. Takai, H.; Kato, A.; Kinoshita, Y.; Ishiguro, T.; Takai, Y.; Ohtani, Y.; Sugimoto, M.; Suzuki, M. Histopathological analyses of the antitumor activity of anti-glypican-3 antibody (GC33) in human liver cancer xenograft models: The essential role of macrophages. Cancer Biol. Ther. 2009, 8, 930-938. [CrossRef] [PubMed]

225. Phung, Y.; Gao, W.; Man, Y.-G.; Nagata, S.; Ho, M. High-affinity monoclonal antibodies to cell surface tumor antigen glypican-3 generated through a combination of peptide immunization and flow cytometry screening. $m A b s$ 2012, 4, 592-599. [CrossRef] [PubMed]

226. Feng, M.; Gao, W.; Wang, R.; Chen, W.; Man, Y.-G.; Figg, W.D.; Wang, X.W.; Dimitrov, D.S.; Ho, M. Therapeutically targeting glypican-3 via a conformation-specific single-domain antibody in hepatocellular carcinoma. Proc. Natl. Acad. Sci. USA 2013, 110, E1083-E1091. [CrossRef]

227. Park, J.O.; Stephen, Z.; Sun, C.; Veiseh, O.; Kievit, F.M.; Fang, C.; Leung, M.; Mok, H.; Zhang, M. Glypican-3 targeting of liver cancer cells using multifunctional nanoparticles. Mol. Imaging 2011, 10, 00048. [CrossRef]

228. Li, Z.; Zeng, Y.; Zhang, D.; Wu, M.; Wu, L.; Huang, A.; Yang, H.; Liu, X.; Liu, J. Glypican-3 antibody functionalized Prussian blue nanoparticles for targeted MR imaging and photothermal therapy of hepatocellular carcinoma. J. Mater. Chem. B 2014, 2 3686-3696. [CrossRef]

229. Kolhatkar, R.; Lote, A.; Khambhati, H. Active tumor targeting of nanomaterials using folic acid, transferrin and integrin receptors. Curr. Drug Discov. Technol. 2011, 8, 197-206. [CrossRef]

230. Crielaard, B.J.; Lammers, T.; Rivella, S. Targeting iron metabolism in drug discovery and delivery. Nat. Rev. Drug Discov. 2017, 16, 400. [CrossRef] [PubMed]

231. Holmström, P.; Gåfvels, M.; Eriksson, L.C.; Dzikaite, V.; Hultcrantz, R.; Eggertsen, G.; Stål, P. Expression of iron regulatory genes in a rat model of hepatocellular carcinoma. Liver Int. 2006, 26, 976-985. [CrossRef]

232. Sakurai, K.; Sohda, T.; Ueda, S.-i.; Tanaka, T.; Hirano, G.; Yokoyama, K.; Morihara, D.; Aanan, A.; Takeyama, Y.; Irie, M. Immunohistochemical demonstration of transferrin receptor 1 and 2 in human hepatocellular carcinoma tissue. Hepato-Gastroenterology 2014, 61, 426-430. [PubMed]

233. Tang, J.; Wang, Q.; Yu, Q.; Qiu, Y.; Mei, L.; Wan, D.; Wang, X.; Li, M.; He, Q. A stabilized retro-inverso peptide ligand of transferrin receptor for enhanced liposome-based hepatocellular carcinoma-targeted drug delivery. Acta Biomater. 2019, 83, 379-389. [CrossRef] [PubMed] 
234. Daniels, T.R.; Delgado, T.; Rodriguez, J.A.; Helguera, G.; Penichet, M.L. The transferrin receptor part I: Biology and targeting with cytotoxic antibodies for the treatment of cancer. Clin. Immunol. 2006, 121, 144-158. [CrossRef] [PubMed]

235. Prutki, M.; Poljak-Blazi, M.; Jakopovic, M.; Tomas, D.; Stipancic, I.; Zarkovic, N. Altered iron metabolism, transferrin receptor 1 and ferritin in patients with colon cancer. Cancer Lett. 2006, 238, 188-196. [CrossRef] [PubMed]

236. Jefferies, W.A.; Brandon, M.R.; Hunt, S.V.; Williams, A.F.; Gatter, K.C.; Mason, D.Y. Transferrin receptor on endothelium of brain capillaries. Nature 1984, 312, 162-163. [CrossRef] [PubMed]

237. Huang, R.; Ke, W.; Liu, Y.; Jiang, C.; Pei, Y. The use of lactoferrin as a ligand for targeting the polyamidoamine-based gene delivery system to the brain. Biomaterials 2008, 29, 238-246. [CrossRef]

238. Gomme, P.T.; McCann, K.B.; Bertolini, J. Transferrin: Structure, function and potential therapeutic actions. Drug Discov. Today 2005, 10, 267-273. [CrossRef]

239. Huang, R.-Q.; Qu, Y.-H.; Ke, W.-L.; Zhu, J.-H.; Pei, Y.-Y.; Jiang, C. Efficient gene delivery targeted to the brain using a transferrinconjugated polyethyleneglycol-modified polyamidoamine dendrimer. Fed. Am. Soc. Exp. Biol. J. 2007, 21, 1117-1125. [CrossRef] [PubMed]

240. Wang, Y.; Chen, J.-T.; Yan, X.-P. Fabrication of transferrin functionalized gold nanoclusters/graphene oxide nanocomposite for turn-on near-infrared fluorescent bioimaging of cancer cells and small animals. Anal. Chem. 2013, 85, 2529-2535. [CrossRef] [PubMed]

241. Ulbrich, K.; Hekmatara, T.; Herbert, E.; Kreuter, J. Transferrin-and transferrin-receptor-antibody-modified nanoparticles enable drug delivery across the blood-brain barrier (BBB). Eur. J. Pharm. Biopharm. 2009, 71, 251-256. [CrossRef] [PubMed]

242. Malarvizhi, G.L.; Retnakumari, A.P.; Nair, S.; Koyakutty, M. Transferrin targeted core-shell nanomedicine for combinatorial delivery of doxorubicin and sorafenib against hepatocellular carcinoma. Nanomed. Nanotechnol. Biol. Med. 2014, 10, 1649-1659. [CrossRef]

243. Parab, H.J.; Huang, J.-H.; Lai, T.-C.; Jan, Y.-H.; Liu, R.-S.; Wang, J.-L.; Hsiao, M.; Chen, C.-H.; Hwu, Y.-K.; Tsai, D.P. Biocompatible transferrin-conjugated sodium hexametaphosphate-stabilized gold nanoparticles: Synthesis, characterization, cytotoxicity and cellular uptake. Nanotechnology 2011, 22, 395706. [CrossRef]

244. Golla, K.; Cherukuvada, B.; Ahmed, F.; Kondapi, A.K. Efficacy, safety and anticancer activity of protein nanoparticle-based delivery of doxorubicin through intravenous administration in rats. PLoS ONE 2012, 7, e51960. [CrossRef] [PubMed]

245. Han, L.; Huang, R.; Li, J.; Liu, S.; Huang, S.; Jiang, C. Plasmid pORF-hTRAIL and doxorubicin co-delivery targeting to tumor using peptide-conjugated polyamidoamine dendrimer. Biomaterials 2011, 32, 1242-1252. [CrossRef] [PubMed]

246. Luo, L.-Z.; Jin, H.-W.; Huang, H.-Q. Transferrin-cisplatin specifically deliver cisplatin to HepG2 cells in vitro and enhance cisplatin cytotoxicity. J. Proteom. 2012, 77, 237-250. [CrossRef] [PubMed]

247. Lu, Q.; Teng, G.-J.; Zhang, Y.; Niu, H.-Z.; Zhu, G.-Y.; An, Y.-L.; Yu, H.; Li, G.-Z.; Qiu, D.-H.; Wu, C.-G. Enhancement of p53 gene transfer efficiency in hepatic tumor mediated by transferrin receptor through trans-arterial delivery. Cancer Biol. Ther. 2008, 7, 218-224. [CrossRef] [PubMed]

248. Jing, F.; Li, J.; Liu, D.; Wang, C.; Sui, Z. Dual ligands modified double targeted nano-system for liver targeted gene delivery. Pharm. Biol. 2013, 51, 643-649. [CrossRef] [PubMed]

249. Pan, Y.-L.; Cai, J.-Y.; Qin, L.; Wang, H. Atomic force microscopy-based cell nanostructure for ligand-conjugated quantum dot endocytosis. Acta Biochim. Biophys. Sin. 2006, 38, 646-652. [CrossRef]

250. Seol, J.; Heo, D.; Kim, H.; Yoon, J.; Choi, B.; Lee, H.; Kim, N.; Kim, C. Selective gene expression in hepatic tumor with trans-arterial delivery of DNA/liposome/transferrin complex. In Vivo 2000, 14, 513-517.

251. Liu, M.-C.; Liu, L.; Wang, X.-R.; Shuai, W.-P.; Hu, Y.; Han, M.; Gao, J.-Q. Folate receptor-targeted liposomes loaded with a diacid metabolite of norcantharidin enhance antitumor potency for $\mathrm{H} 22$ hepatocellular carcinoma both in vitro and in vivo. Int. J. Nanomed. 2016, 11, 1395. [CrossRef] [PubMed]

252. Gabizon, A.; Horowitz, A.T.; Goren, D.; Tzemach, D.; Shmeeda, H.; Zalipsky, S. In vivo fate of folate-targeted polyethylene-glycol liposomes in tumor-bearing mice. Clin. Cancer Res. 2003, 9, 6551-6559. [PubMed]

253. Huang, Y.; Yang, T.; Zhang, W.; Lu, Y.; Ye, P.; Yang, G.; Li, B.; Qi, S.; Liu, Y.; He, X. A novel hydrolysis-resistant lipophilic folate derivative enables stable delivery of targeted liposomes in vivo. Int. J. Nanomed. 2014, 9, 4581.

254. Gao, J.-Q.; Lv, Q.; Li, L.-M.; Tang, X.-J.; Li, F.-Z.; Hu, Y.-L.; Han, M. Glioma targeting and blood-brain barrier penetration by dual-targeting doxorubincin liposomes. Biomaterials 2013, 34, 5628-5639. [CrossRef] [PubMed]

255. Zhao, X.B.; Lee, R.J. Tumor-selective targeted delivery of genes and antisense oligodeoxyribonucleotides via the folate receptor. Adv. Drug Deliv. Rev. 2004, 56, 1193-1204. [CrossRef]

256. Koirala, N.; Das, D.; Fayazzadeh, E.; Sen, S.; McClain, A.; Puskas, J.E.; Drazba, J.A.; McLennan, G. Folic acid conjugated polymeric drug delivery vehicle for targeted cancer detection in hepatocellular carcinoma. J. Biomed. Mater. Res. Part A 2019, 107, $2522-2535$. [CrossRef] [PubMed]

257. Zwicke, G.L.; Ali Mansoori, G.; Jeffery, C.J. Utilizing the folate receptor for active targeting of cancer nanotherapeutics. Nano Rev. 2012, 3, 18496. [CrossRef] [PubMed]

258. Parker, N.; Turk, M.J.; Westrick, E.; Lewis, J.D.; Low, P.S.; Leamon, C.P. Folate receptor expression in carcinomas and normal tissues determined by a quantitative radioligand binding assay. Anal. Biochem. 2005, 338, 284-293. [CrossRef]

259. Kelemen, L.E. The role of folate receptor $\alpha$ in cancer development, progression and treatment: Cause, consequence or innocent bystander? Int. J. Cancer 2006, 119, 243-250. [CrossRef] [PubMed] 
260. Choi, S.-W.; Mason, J.B. Folate and carcinogenesis: An integrated scheme. J. Nutr. 2000, 130, 129-132. [CrossRef] [PubMed]

261. Blount, B.C.; Mack, M.M.; Wehr, C.M.; MacGregor, J.T.; Hiatt, R.A.; Wang, G.; Wickramasinghe, S.N.; Everson, R.B.; Ames, B.N. Folate deficiency causes uracil misincorporation into human DNA and chromosome breakage: Implications for cancer and neuronal damage. Proc. Natl. Acad. Sci. USA 1997, 94, 3290-3295. [CrossRef] [PubMed]

262. Ghalehkhondabi, V.; Soleymani, M.; Fazlali, A. Folate-targeted nanomicelles containing silibinin as an active drug delivery system for liver cancer therapy. J. Drug Deliv. Sci. Technol. 2021, 61, 102157. [CrossRef]

263. Bwatanglang, I.B.; Mohammad, F.; Yusof, N.A.; Abdullah, J.; Alitheen, N.B.; Hussein, M.Z.; Abu, N.; Mohammed, N.E.; Nordin, N.; Zamberi, N.R. In vivo tumor targeting and anti-tumor effects of 5-fluororacil loaded, folic acid targeted quantum dot system. J. Colloid Interface Sci. 2016, 480, 146-158. [CrossRef]

264. Abdelmoneem, M.A.; Mahmoud, M.; Zaky, A.; Helmy, M.W.; Sallam, M.; Fang, J.-Y.; Elkhodairy, K.A.; Elzoghby, A.O. Dualtargeted casein micelles as green nanomedicine for synergistic phytotherapy of hepatocellular carcinoma. J. Control. Release 2018, 287, 78-93. [CrossRef]

265. Maghsoudinia, F.; Tavakoli, M.B.; Samani, R.K.; Motaghi, H.; Hejazi, S.H.; Mehrgardi, M.A. Bevacizumab and folic acid dualtargeted gadolinium-carbon dots for fluorescence/magnetic resonance imaging of hepatocellular carcinoma. J. Drug Deliv. Sci. Technol. 2021, 61, 102288. [CrossRef]

266. Gao, W.; Jia, X.; Wu, J.; Song, Y.; Yin, J.; Zhang, M.; Qiu, N.; Li, X.; Wu, P.; Qi, X. Preparation and evaluation of folate-decorated human serum albumin nanoparticles for the targeted delivery of sorafenib to enhance antihepatocarcinoma efficacy. J. Drug Deliv. Sci. Technol. 2019, 54, 101349. [CrossRef]

267. Shi, X.; He, D.; Tang, G.; Tang, Q.; Xiong, R.; Ouyang, H.; Yu, C.-y. Fabrication and characterization of a folic acid-bound 5-fluorouracil loaded quantum dot system for hepatocellular carcinoma targeted therapy. RSC Adv. 2018, 8, 19868-19878. [CrossRef]

268. Bi, J.; Lu, Y.; Dong, Y.; Gao, P. Synthesis of folic acid-modified DOX@ ZIF-8 nanoparticles for targeted therapy of liver Cancer. J. Nanomater. 2018, 2018, 1357812. [CrossRef]

269. Lu, T.; Nong, Z.; Wei, L.; Wei, M.; Li, G.; Wu, N.; Liu, C.; Tang, B.; Qin, Q.; Li, X. Preparation and anti-cancer activity of transferrin/folic acid double-targeted graphene oxide drug delivery system. J. Biomater. Appl. 2020, 35, 15-27. [CrossRef] [PubMed]

270. Zagami, R.; Rapozzi, V.; Piperno, A.; Scala, A.; Triolo, C.; Trapani, M.; Xodo, L.E.; Monsù Scolaro, L.; Mazzaglia, A. Folatedecorated amphiphilic Cyclodextrins as cell-targeted Nanophototherapeutics. Biomacromolecules 2019, 20, 2530-2544. [CrossRef] [PubMed]

271. Huang, S.; Duan, S.; Wang, J.; Bao, S.; Qiu, X.; Li, C.; Liu, Y.; Yan, L.; Zhang, Z.; Hu, Y. Folic-acid-mediated functionalized gold nanocages for targeted delivery of anti-miR-181b in combination of gene therapy and photothermal therapy against hepatocellular carcinoma. Adv. Funct. Mater. 2016, 26, 2532-2544. [CrossRef]

272. Shao, D.; Li, J.; Pan, Y.; Zhang, X.; Zheng, X.; Wang, Z.; Zhang, M.; Zhang, H.; Chen, L. Noninvasive theranostic imaging of HSV-TK/GCV suicide gene therapy in liver cancer by folate-targeted quantum dot-based liposomes. Biomater. Sci. 2015, 3, 833-841. [CrossRef]

273. Chen, Y.; Liu, W.; Shang, Y.; Cao, P.; Cui, J.; Li, Z.; Yin, X.; Li, Y. Folic acid-nanoscale gadolinium-porphyrin metal-organic frameworks: Fluorescence and magnetic resonance dual-modality imaging and photodynamic therapy in hepatocellular carcinoma. Int. J. Nanomed. 2019, 14, 57. [CrossRef] [PubMed]

274. Ling, D.; Xia, H.; Park, W.; Hackett, M.J.; Song, C.; Na, K.; Hui, K.M.; Hyeon, T. pH-sensitive nanoformulated triptolide as a targeted therapeutic strategy for hepatocellular carcinoma. Am. Chem. Soc. Nano 2014, 8, 8027-8039. [CrossRef] [PubMed]

275. Shen, W.-J.; Azhar, S.; Kraemer, F.B. SR-B1: A unique multifunctional receptor for cholesterol influx and efflux. Annu. Rev. Physiol. 2018, 80, 95-116. [CrossRef] [PubMed]

276. Shen, W.-J.; Azhar, S.; Kraemer, F.B. Lipid droplets and steroidogenic cells. Exp. Cell Res. 2016, 340, 209-214. [CrossRef] [PubMed]

277. Lu, M.; Hu, X.-H.; Li, Q.; Xiong, Y.; Hu, G.-J.; Xu, J.-J.; Zhao, X.-N.; Wei, X.-X.; Chang, C.C.; Liu, Y.-K. A specific cholesterol metabolic pathway is established in a subset of HCCs for tumor growth. J. Mol. Cell Biol. 2013, 5, 404-415. [CrossRef] [PubMed]

278. Lacko, A.G.; Nair, M.; Paranjape, S.; Johnson, S.; McConathy, W.J. High density lipoprotein complexes as delivery vehicles for anticancer drugs. Anticancer Res. 2002, 22, 2045-2050. [PubMed]

279. Trigatti, B.L. SR-B1 and PDZK1: Partners in HDL regulation. Curr. Opin. Lipidol. 2017, 28, 201-208. [CrossRef] [PubMed]

280. Mooberry, L.K.; Sabnis, N.A.; Panchoo, M.; Nagarajan, B.; Lacko, A.G. Targeting the SR-B1 receptor as a gateway for cancer therapy and imaging. Front. Pharmacol. 2016, 7, 466. [CrossRef] [PubMed]

281. Ganjali, S.; Ricciuti, B.; Pirro, M.; Butler, A.E.; Atkin, S.L.; Banach, M.; Sahebkar, A. High-density lipoprotein components and functionality in cancer: State-of-the-art. Trends Endocrinol. Metab. 2019, 30, 12-24. [CrossRef]

282. Plebanek, M.P.; Bhaumik, D.; Thaxton, C.S. HDL and the golden key to cancer immunity? Oncoscience 2018, 5, 164. [CrossRef]

283. Henrich, S.E.; Thaxton, C.S. An update on synthetic high-density lipoprotein-like nanoparticles for cancer therapy. Expert Rev. Anticancer Ther. 2019, 19, 515-528. [CrossRef]

284. Luthi, A.J.; Lyssenko, N.N.; Quach, D.; McMahon, K.M.; Millar, J.S.; Vickers, K.C.; Rader, D.J.; Phillips, M.C.; Mirkin, C.A.; Thaxton, C.S. Robust passive and active efflux of cellular cholesterol to a designer functional mimic of high density lipoprotein. J. Lipid Res. 2015, 56, 972-985. [CrossRef] 
285. Yang, M.; Jin, H.; Chen, J.; Ding, L.; Ng, K.K.; Lin, Q.; Lovell, J.F.; Zhang, Z.; Zheng, G. Efficient cytosolic delivery of siRNA using HDL-mimicking nanoparticles. Small 2011, 7, 568-573. [CrossRef] [PubMed]

286. Wang, J.; Zheng, C.; Zhai, Y.; Cai, Y.; Lee, R.J.; Xing, J.; Wang, H.; Zhu, H.H.; Teng, L.; Li, Y. High-density lipoprotein modulates tumor-associated macrophage for chemoimmunotherapy of hepatocellular carcinoma. Nano Today 2021, 37, 101064. [CrossRef]

287. Cruz, W.; Huang, H.; Barber, B.; Pasini, E.; Ding, L.; Zheng, G.; Chen, J.; Bhat, M. Lipoprotein-Like Nanoparticle Carrying Small Interfering RNA Against Spalt-Like Transcription Factor 4 Effectively Targets Hepatocellular Carcinoma Cells and Decreases Tumor Burden. Hepatol. Commun. 2020, 4, 769-782. [CrossRef] [PubMed]

288. Yuan, Y.; Wang, W.; Wang, B.; Zhu, H.; Zhang, B.; Feng, M. Delivery of hydrophilic drug doxorubicin hydrochloride-targeted liver using apoAI as carrier. J. Drug Target. 2013, 21, 367-374. [CrossRef]

289. Jiang, Y.-Q.; Wang, H.-R.; Li, H.-P.; Hao, H.-J.; Zheng, Y.-L.; Gu, J. Targeting of hepatoma cell and suppression of tumor growth by a novel 12mer peptide fused to superantigen TSST-1. Mol. Med. 2006, 12, 81-87. [CrossRef] [PubMed]

290. Savier, E.; Simon-Gracia, L.; Charlotte, F.; Tuffery, P.; Teesalu, T.; Scatton, O.; Rebollo, A. Bi-Functional Peptides as a New Therapeutic Tool for Hepatocellular Carcinoma. Pharmaceutics 2021, 13, 1631. [CrossRef]

291. Nie, X.; Liu, Y.; Li, M.; Yu, X.; Yuan, W.; Huang, S.; Ren, D.; Wang, Y.; Wang, Y. SP94 Peptide-Functionalized PEG-PLGA nanoparticle loading with cryptotanshinone for targeting therapy of hepatocellular carcinoma. AAPS PharmSciTech 2020, 21, 124. [CrossRef] [PubMed]

292. Jiang, B.; Yan, L.; Zhang, J.; Zhou, M.; Shi, G.; Tian, X.; Fan, K.; Hao, C.; Yan, X. Biomineralization synthesis of the cobalt nanozyme in SP94-ferritin nanocages for prognostic diagnosis of hepatocellular carcinoma. Am. Chem. Soc. Appl. Mater. Interfaces 2019, 11, 9747-9755. [CrossRef] [PubMed]

293. Zhang, J.; Wang, X.; Cheng, L.; Yuan, J.; Zhong, Z. SP94 peptide mediating highly specific and efficacious delivery of polymersomal doxorubicin hydrochloride to hepatocellular carcinoma in vivo. Colloids Surf. B Biointerfaces 2021, 197, 111399. [CrossRef] [PubMed]

294. Anand, P.; Filipenko, P.; Huaman, J.; Lyudmer, M.; Hossain, M.; Santamaria, C.; Huang, K. Antitumor effects of Tv1 venom peptide in liver cancer. bioRxiv 2019, 518340. [CrossRef]

295. Liu, L.; Chen, X.; Xie, S.; Zhang, C.; Qiu, Z.; Zhu, F. Variant 1 of KIAA0101, overexpressed in hepatocellular carcinoma, prevents doxorubicin-induced apoptosis by inhibiting p53 activation. Hepatology 2012, 56, 1760-1769. [CrossRef] [PubMed]

296. Liu, L.; Liu, Y.; Chen, X.; Wang, M.; Zhou, Y.; Zhou, P.; Li, W.; Zhu, F. Variant 2 of KIAA0101, antagonizing its oncogenic variant 1 , might be a potential therapeutic strategy in hepatocellular carcinoma. Oncotarget 2017, 8, 43990. [CrossRef] [PubMed]

297. Luan, X.; Wu, Y.; Shen, Y.-W.; Zhang, H.; Zhou, Y.-D.; Chen, H.-Z.; Nagle, D.G.; Zhang, W.-D. Cytotoxic and antitumor peptides as novel chemotherapeutics. Nat. Prod. Rep. 2021, 38, 7-17. [CrossRef]

298. Liu, B.H.; Jobichen, C.; Chia, C.B.; Chan, T.H.M.; Tang, J.P.; Chung, T.X.; Li, J.; Poulsen, A.; Hung, A.W.; Koh-Stenta, X. Targeting cancer addiction for SALL4 by shifting its transcriptome with a pharmacologic peptide. Proc. Natl. Acad. Sci. USA 2018, 115, E7119-E7128. [CrossRef] [PubMed]

299. Kruskal, J.B.; Robson, S.C.; Franks, J.J.; Kirsch, R.E. Elevated fibrin-related and fibrinogen-related antigens in patients with liver disease. Hepatology 1992, 16, 920-923. [CrossRef] [PubMed]

300. Schmithals, C.; Köberle, V.; Korkusuz, H.; Pleli, T.; Kakoschky, B.; Augusto, E.A.; Ibrahim, A.A.; Arencibia, J.M.; Vafaizadeh, V.; Groner, B. Improving drug penetrability with iRGD leverages the therapeutic response to sorafenib and doxorubicin in hepatocellular carcinoma. Cancer Res. 2015, 75, 3147-3154. [CrossRef] [PubMed]

301. Chen, J.-T.; Ma, R.; Sun, S.-C.; Zhu, X.-F.; Xu, X.-L.; Mu, Q. Synthesis and biological evaluation of cyclopeptide GG-8-6 and its analogues as anti-hepatocellular carcinoma agents. Bioorg. Med. Chem. 2018, 26, 609-622. [CrossRef]

302. Gong, F.; Wang, R.; Zhu, Z.; Duan, J.; Teng, X.; Cui, Z.-K. Drug-interactive mPEG-b-PLA-Phe (Boc) micelles enhance the tolerance and anti-tumor efficacy of docetaxel. Drug Deliv. 2020, 27, 238-247. [CrossRef]

303. Zhang, X.; Lin, C.; Chan, W.; Liu, K.; Lu, A.; Lin, G.; Hu, R.; Shi, H.; Zhang, H.; Yang, Z. Dual-functional liposomes with carbonic anhydrase IX antibody and BR2 peptide modification effectively improve intracellular delivery of cantharidin to treat orthotopic hepatocellular carcinoma mice. Molecules 2019, 24, 3332. [CrossRef]

304. Wang, S.; Zhu, J.; Liu, Y. A novel anti-adhesion peptide ( $\beta 3$ ) inhibits hepatocellular carcinoma activity in vitro and in vivo. Oncol. Lett. 2016, 12, 4744-4748. [CrossRef]

305. Chen, Y.-L.S.; Li, J.-H.; Yu, C.-Y.; Lin, C.-J.; Chiu, P.-H.; Chen, P.-W.; Lin, C.-C.; Chen, W.-J. Novel cationic antimicrobial peptide GW-H1 induced caspase-dependent apoptosis of hepatocellular carcinoma cell lines. Peptides 2012, 36, 257-265. [CrossRef] [PubMed]

306. Kardani, K.; Bolhassani, A. Antimicrobial/anticancer peptides: Bioactive molecules and therapeutic agents. Immunotherapy 2021, 13, 669-684. [CrossRef] [PubMed]

307. Paiva, A.D.; de Oliveira, M.D.; de Paula, S.O.; Baracat-Pereira, M.C.; Breukink, E.; Mantovani, H.C. Toxicity of bovicin HC5 against mammalian cell lines and the role of cholesterol in bacteriocin activity. Microbiology 2012, 158, 2851-2858. [CrossRef]

308. Pittala, S.; Krelin, Y.; Shoshan-Barmatz, V. Targeting liver cancer and associated pathologies in mice with a mitochondrial VDAC1-based peptide. Neoplasia 2018, 20, 594-609. [CrossRef] [PubMed]

309. Zhao, M.; Wang, Y.; Liu, Y.; Zhang, W.; Liu, Y.; Yang, X.; Cao, Y.; Wang, S. C7 peptide inhibits hepatocellular carcinoma metastasis by targeting the HGF/c-met signaling pathway. Cancer Biol. Ther. 2019, 20, 1430-1442. [CrossRef] [PubMed] 
310. Tsang, F.H.; Lee, N.P.; Luk, J.M. The use of small peptides in the diagnosis and treatment of hepatocellular carcinoma. Protein Pept. Lett. 2009, 16, 530-538. [CrossRef] [PubMed]

311. Sawada, Y.; Yoshikawa, T.; Ofuji, K.; Yoshimura, M.; Tsuchiya, N.; Takahashi, M.; Nobuoka, D.; Gotohda, N.; Takahashi, S.; Kato, Y. Phase II study of the GPC3-derived peptide vaccine as an adjuvant therapy for hepatocellular carcinoma patients. Oncoimmunology 2016, 5, e1129483. [CrossRef]

312. Zhang, Q.; Han, Z.; Tao, J.; Zhao, M.; Zhang, W.; Li, P.; Tang, L.; Gu, Y. An innovative peptide with high affinity to GPC3 for hepatocellular carcinoma diagnosis. Biomater. Sci. 2019, 7, 159-167. [CrossRef] [PubMed]

313. Tsuchiya, N.; Yoshikawa, T.; Fujinami, N.; Saito, K.; Mizuno, S.; Sawada, Y.; Endo, I.; Nakatsura, T. Immunological efficacy of glypican-3 peptide vaccine in patients with advanced hepatocellular carcinoma. Oncoimmunology 2017, 6, e1346764. [CrossRef]

314. Xia, L.; Wu, Y.; Ma, J.; Yang, J.; Zhang, F. The antibacterial peptide from Bombyx mori cecropinXJ induced growth arrest and apoptosis in human hepatocellular carcinoma cells. Oncol. Lett. 2016, 12, 57-62. [CrossRef] [PubMed]

315. Nobuoka, D.; Yoshikawa, T.; Sawada, Y.; Fujiwara, T.; Nakatsura, T. Peptide vaccines for hepatocellular carcinoma. Hum. Vaccines Immunother. 2013, 9, 210-212. [CrossRef] [PubMed]

316. Xu, J.; Huang, F.; Yao, Z.; Jia, C.; Xiong, Z.; Liang, H.; Lin, N.; Deng, M. Inhibition of cyclin E1 sensitizes hepatocellular carcinoma cells to regorafenib by mcl-1 suppression. Cell Commun. Signal. 2019, 17, 85. [CrossRef] [PubMed]

317. Li, T.; Xue, Y.; Wang, G.; Gu, T.; Li, Y.; Zhu, Y.Y.; Chen, L. Multi-target siRNA: Therapeutic strategy for hepatocellular carcinoma J. Cancer 2016, 7, 1317. [CrossRef] [PubMed]

318. Yao, Y.; Wang, T.; Liu, Y.; Zhang, N. Co-delivery of sorafenib and VEGF-siRNA via pH-sensitive liposomes for the synergistic treatment of hepatocellular carcinoma. Artif. Cells Nanomed. Biotechnol. 2019, 47, 1374-1383. [CrossRef]

319. Younis, M.A.; Khalil, I.A.; Elewa, Y.H.; Kon, Y.; Harashima, H. Ultra-small lipid nanoparticles encapsulating sorafenib and midkine-siRNA selectively-eradicate sorafenib-resistant hepatocellular carcinoma in vivo. J. Control. Release 2021, 331, 335-349. [CrossRef] [PubMed]

320. Liu, H.; Wang, S.; Sun, H.; Pan, Z.; Zhou, W.; Wu, M. Inhibition of tumorigenesis and invasion of hepatocellular carcinoma by siRNA-mediated silencing of the livin gene. Mol. Med. Rep. 2010, 3, 903-907.

321. Cho, S.B.; Lee, W.S.; Park, Y.L.; Kim, N.; Oh, H.H.; Kim, M.Y.; Oak, C.Y.; Chung, C.Y.; Park, H.C.; Kim, J.S. Livin is associated with the invasive and oncogenic phenotypes of human hepatocellular carcinoma cells. Hepatol. Res. 2015, 45, 448-457. [CrossRef] [PubMed]

322. Xie, F.; Yuan, Y.; Xie, L.; Ran, P.; Xiang, X.; Huang, Q.; Qi, G.; Guo, X.; Xiao, C.; Zheng, S. miRNA-320a inhibits tumor proliferation and invasion by targeting c-Myc in human hepatocellular carcinoma. OncoTargets Ther. 2017, 10, 885. [CrossRef]

323. Liu, R.; Li, Y.; Tian, L.; Shi, H.; Wang, J.; Liang, Y.; Sun, B.; Wang, S.; Zhou, M.; Wu, L. Gankyrin drives metabolic reprogramming to promote tumorigenesis, metastasis and drug resistance through activating $\beta$-catenin/c-Myc signaling in human hepatocellular carcinoma. Cancer Lett. 2019, 443, 34-46. [CrossRef]

324. Li, H.; Fu, X.; Chen, Y.; Hong, Y.; Tan, Y.; Cao, H.; Wu, M.; Wang, H. Use of adenovirus-delivered siRNA to target oncoprotein p28GANK in hepatocellular carcinoma. Gastroenterology 2005, 128, 2029-2041. [CrossRef]

325. Liu, J.-Y.; Chiang, T.; Liu, C.-H.; Chern, G.-G.; Lin, T.-T.; Gao, D.-Y.; Chen, Y. Delivery of siRNA using CXCR4-targeted nanoparticles modulates tumor microenvironment and achieves a potent antitumor response in liver cancer. Mol. Ther. 2015, 23, 1772-1782. [CrossRef] [PubMed]

326. Li, L.; Wang, R.; Wilcox, D.; Sarthy, A.; Lin, X.; Huang, X.; Tian, L.; Dande, P.; Hubbard, R.D.; Hansen, T.M. Developing lipid nanoparticle-based siRNA therapeutics for hepatocellular carcinoma using an integrated approach. Mol. Cancer Ther. 2013, 12, 2308-2318. [CrossRef]

327. Ashley, C.E.; Carnes, E.C.; Phillips, G.K.; Padilla, D.; Durfee, P.N.; Brown, P.A.; Hanna, T.N.; Liu, J.; Phillips, B.; Carter, M.B. The targeted delivery of multicomponent cargos to cancer cells by nanoporous particle-supported lipid bilayers. Nat. Mater. 2011, 10, 389-397. [CrossRef] [PubMed]

328. Han, L.; Tang, C.; Yin, C. Oral delivery of shRNA and siRNA via multifunctional polymeric nanoparticles for synergistic cancer therapy. Biomaterials 2014, 35, 4589-4600. [CrossRef] [PubMed]

329. Ding, Y.; Wang, W.; Feng, M.; Wang, Y.; Zhou, J.; Ding, X.; Zhou, X.; Liu, C.; Wang, R.; Zhang, Q. A biomimetic nanovectormediated targeted cholesterol-conjugated siRNA delivery for tumor gene therapy. Biomaterials 2012, 33, 8893-8905. [CrossRef]

330. Chen, J.; Zhu, S.; Tong, L.; Li, J.; Chen, F.; Han, Y.; Zhao, M.; Xiong, W. Superparamagnetic iron oxide nanoparticles mediated 131 I-hVEGF siRNA inhibits hepatocellular carcinoma tumor growth in nude mice. BMC Cancer 2014, 14, 114. [CrossRef]

331. Wu, C.; Gong, F.; Pang, P.; Shen, M.; Zhu, K.; Cheng, D.; Liu, Z.; Shan, H. An RGD-modified MRI-visible polymeric vector for targeted siRNA delivery to hepatocellular carcinoma in nude mice. PLoS ONE 2013, 8, e66416.

332. Varshosaz, J.; Farzan, M. Nanoparticles for targeted delivery of therapeutics and small interfering RNAs in hepatocellular carcinoma. World J. Gastroenterol. 2015, 21, 12022. [CrossRef]

333. Liu, C.; Yu, J.; Yu, S.; Lavker, R.M.; Cai, L.; Liu, W.; Yang, K.; He, X.; Chen, S. MicroRNA-21 acts as an oncomir through multiple targets in human hepatocellular carcinoma. J. Hepatol. 2010, 53, 98-107. [CrossRef]

334. Su, H.; Yang, J.-R.; Xu, T.; Huang, J.; Xu, L.; Yuan, Y.; Zhuang, S.-M. MicroRNA-101, down-regulated in hepatocellular carcinoma, promotes apoptosis and suppresses tumorigenicity. Cancer Res. 2009, 69, 1135-1142. [CrossRef] [PubMed] 